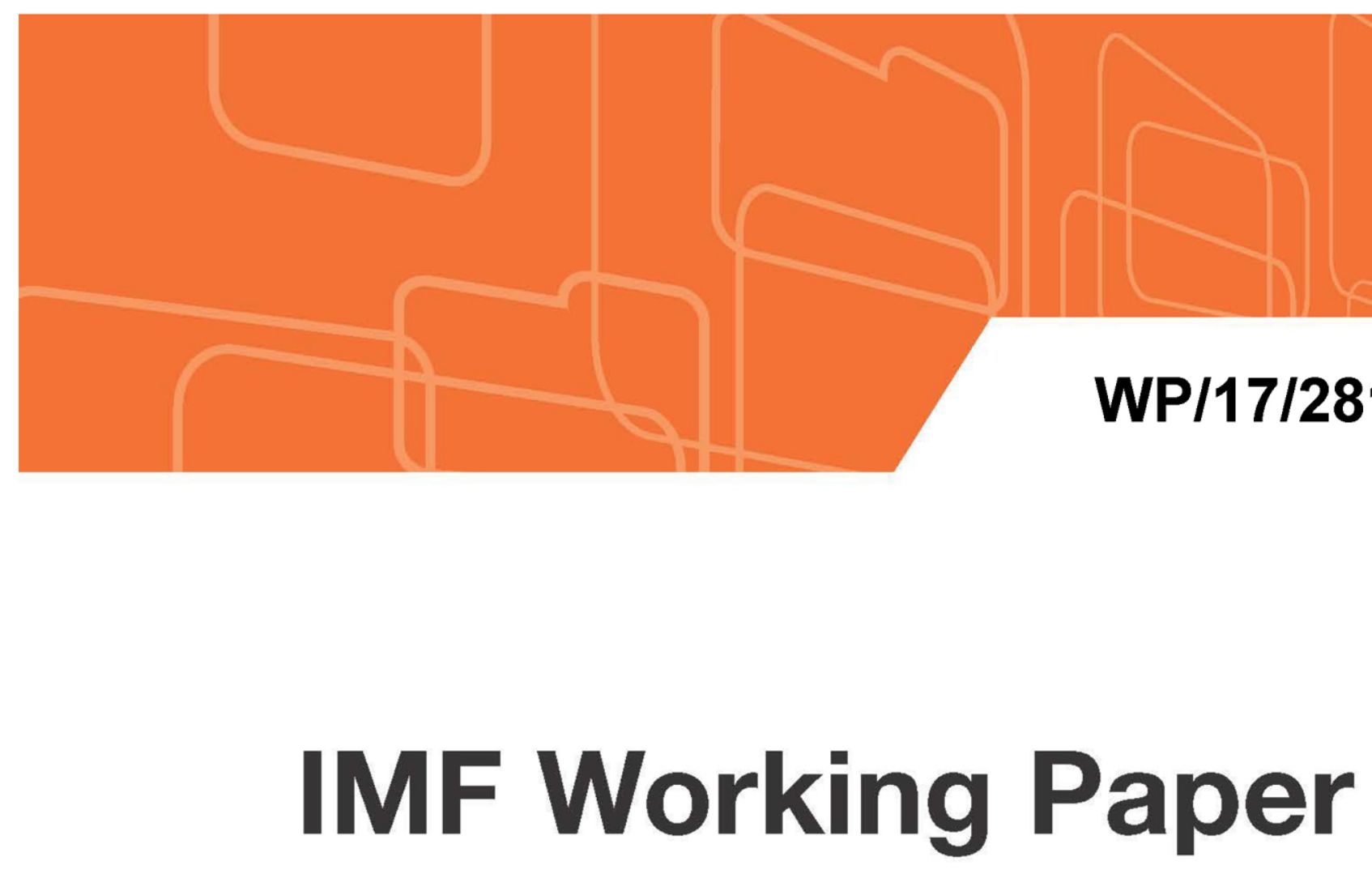

\title{
The Impact of Fiscal Consolidations on Growth in Sub-Saharan Africa
}

by Francisco Arizala, Jesus Gonzalez-Garcia, Charalambos G. Tsangarides, and Mustafa Yenice 


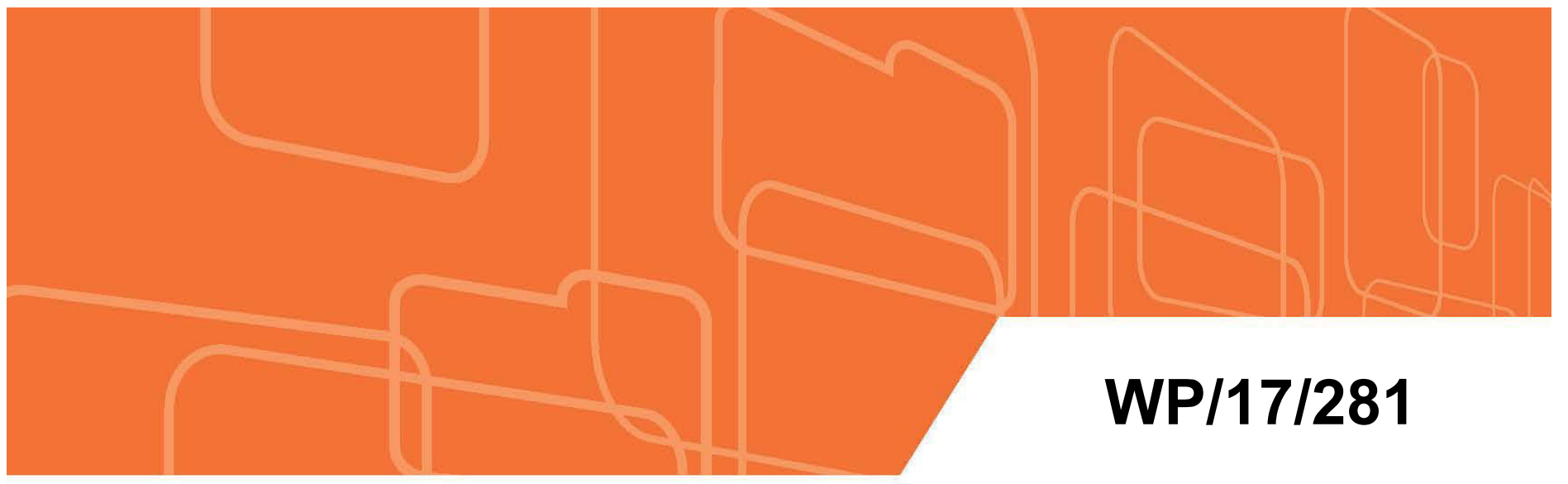

\section{IMF Working Paper}

\section{The Impact of Fiscal Consolidations on Growth in Sub-Saharan Africa}

by Francisco Arizala, Jesus Gonzalez-Garcia, Charalambos G. Tsangarides, and Mustafa Yenice 


\title{
IMF Working Paper
}

\author{
African Department
}

\section{The Impact of Fiscal Consolidations on Growth in Sub-Saharan Africa}

\author{
Prepared by Francisco Arizala, Jesus Gonzalez-Garcia, \\ Charalambos G. Tsangarides, and Mustafa Yenice ${ }^{\dagger}$
}

Authorized for distribution by David Robinson

December 2017

\section{IMF Working Papers describe research in progress by the author(s) and are published to elicit comments and to encourage debate. The views expressed in IMF Working Papers are those of the author(s) and do not necessarily represent the views of the IMF, its Executive Board, or IMF management.}

\begin{abstract}
This paper examines the output effects of changes in public expenditure and revenue in subSaharan African countries during 1990-2016. Fiscal multipliers in sub-Saharan Africa are somewhat smaller than those in advanced and emerging economies. The effect of changes in fiscal policy on output depends on the composition: cutting public investment has a larger effect on output than cutting public consumption or raising revenue. Episodes of fiscal consolidation have short- and medium-term output effects, but here, too, composition matters: fiscal consolidations based on reducing public investment have the largest effect on output, while fiscal consolidations based on revenue mobilization are less harmful than those based on public investment cuts. These findings suggest that the negative impact on growth can be mitigated through the design of fiscal adjustment and the accompanying policy environment.

JEL Classification Numbers: O55, E32, E62, H50.

Keywords: $\quad$ Growth, fiscal consolidations, fiscal multipliers, local projections, Africa.

Authors'E-Mail Addresses: farizala@imf.org; jgonzalezgarcia@imf.org; ctsangarides@imf.org; myenice@imf.org
\end{abstract}

\footnotetext{
† The research underlying this paper was initiated in the context of the preparation of IMF's October 2017 Regional Economic Outlook for Sub-Saharan Africa. We would like to thank Monique Newiak who contributed to this project in its early stages, and Abebe Aemro Selassie, David Robinson, and IMF colleagues for helpful comments and suggestions. The usual disclaimer applies.
} 
Contents

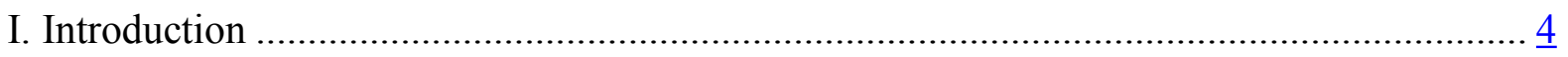

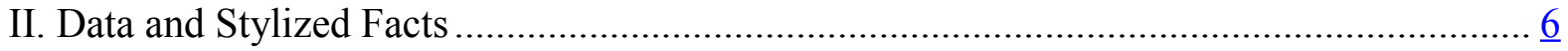

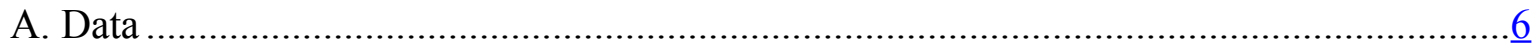

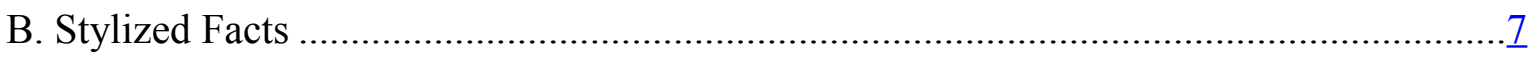

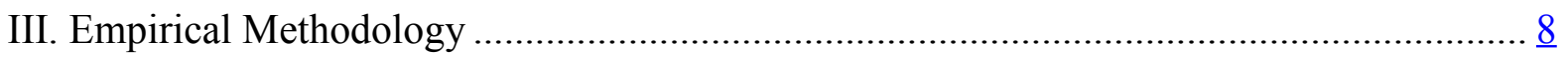

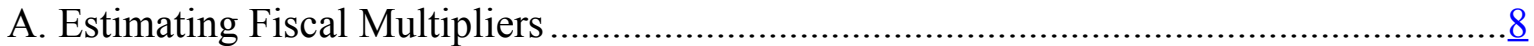

B. Estimating the Effects of Fiscal Consolidations ...........................................................

IV. The Effect of Fiscal Policy on Output .................................................................... 11

A. The Size of the Fiscal Multiplier..........................................................................11

B. Fiscal Multipliers and Country Characteristics .......................................................12

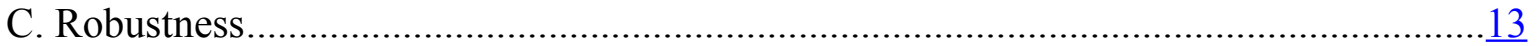

V. Fiscal Consolidations, Economic Activity, and the Role of Mitigation Policies................ 14

A. How Much Does Fiscal Consolidation Hurt? ..........................................................14

B. The Role of Policies and Macroeconomic Factors...................................................15

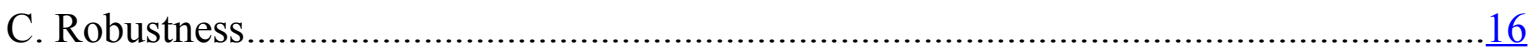

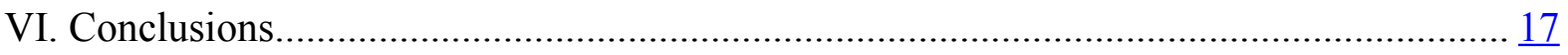

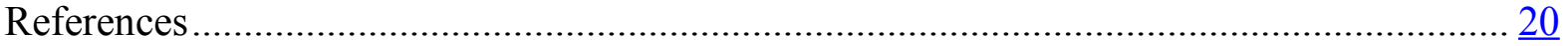

Figures

1. Figure 1: SSA and EMEDEV: Episodes of Commodity Revenue Decline......................... 24

2. Figure 2: SSA and EMEDEV: Spending-based Fiscal Consolidation Episodes ................. 24

3. Figure 3. Change in the Overall Fiscal Balance and Components: Spending-based Fiscal

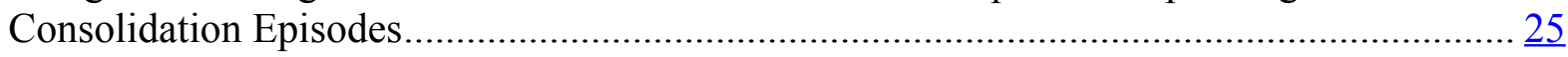

4. Figure 4. SSA and Emerging and Developing Countries: Revenue-based Fiscal Consolidation Episodes................................................................................................... 25

5. Figure 5. SSA: Effect of Fiscal Policy on Output.......................................................... 26

6. Figure 6. SSA: Fiscal Multipliers during Periods of High and Low Growth ..................... 26

7. Figure 7. SSA: Fiscal Multipliers during Periods of High and Low Governance Quality. $\underline{26}$

8. Figure 8. SSA: Fiscal Multipliers during Periods of High and Low Efficiency of Public

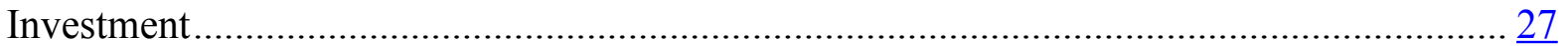

9. Figure 9. SSA: Impact of Spending Based Fiscal Consolidation on Economic Activity ... 27 10. Figure 10. SSA: Impact of Investment, Consumption, and Revenue Based Consolidations

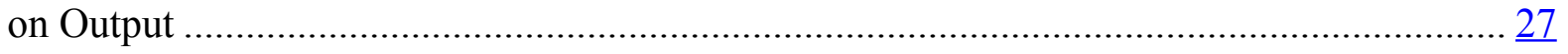

11. Figure 11. SSA: Impact of Tax-Based Consolidation on Economic Activity …………... $\underline{28}$

12. Figure 12. SSA: Impact of Fiscal Consolidations under Different Monetary Conditions $\underline{28}$

13. Figure 13. SSA: Impact of Fiscal Consolidations in Different Debt Environment .......... $\underline{28}$ 
14. Figure 14. SSA: Impact of Fiscal Consolidations and Role of Exchange Rate Flexibility, International Reserves Buffers, and Openness to Trade ...................................................... 29

15. Figure 15. Robustness Checks: Spending-based Consolidation ....................................... $\underline{30}$

Tables

1. Table 1. Variables and Sources...............................................................................

2. Table 2. Estimated Fiscal Multipliers in the Literature ……………………………….... 31

3. Table 3. Comparison of Fiscal Multipliers .................................................................. 31 


\section{INTRODUCTION}

Many sub-Saharan African countries are facing a period of fiscal consolidation in order to ensure macroeconomic stability and sustainable growth. For the resource-intensive countries hit hard by the commodity price collapse, fiscal consolidation is urgent to offset likely permanent revenue losses. For other countries, especially those still growing fast, there may be less urgency for fiscal consolidation but many have seen buffers eroded, and public debt and borrowing costs are on the rise.

Against this backdrop, two related questions arise. How does output typically respond to spending cuts or revenue increases? And what policies can mitigate the impact of fiscal consolidation on output? To answer these questions, this paper examines the output effects of changes in public expenditure and revenue in sub-Saharan African countries during 19902016.

There is large body of literature examining the impact of fiscal policy on output, most of it focusing on advanced countries. Research has focused on several aspects of this relationship including short-term and long-term effects on growth, composition of the fiscal adjustment, presence of nonlinearities in the relationship, and the implications for growth of the interaction of fiscal policy with other macroeconomic variables (see Gupta and others 2005, Chapter 3 in the October 2010 World Economic Outlook, IMF 2014, DeLong and Summers 2012, Baum, Poplawski-Ribeiro, and Weber 2012, Ilzetzki, Mendoza, and Vegh, 2013, Auerbach and Gorodnichenko 2013a, 2013b, Blanchard and Leigh 2013, Batini and others 2014, Dell'Erba, Koloskova, and Poplawski-Ribeiro 2014, Mineshima, Poplawski-Ribeiro, and Weber 2014, and Abiad, Furceri, and Topalova 2016).

In a typical Keynesian model with sticky nominal wages and prices, a fiscal expansionincluding one that maintains a balanced budget - can stimulate economic activity and result in a temporary increase in real GDP growth (Barro and Grossman, 1971). By the same token, a fiscal contraction would lead to a fall in real GDP growth. However, while the assumptions underlying the Keynesian model may hold in advanced countries, they are less likely to do so in developing or emerging market economies. The presence of large informal sectors with flexible wages and prices and shallow financial systems, which facilitate government crowding out of private investment through very high interest rates on the domestic public debt, may diminish the output effect of fiscal adjustment in developing economies. The literature has also discussed the possibility that fiscal consolidations can have positive spillovers for economic activity. For instance, if there are concerns about the sustainability of public finances, a credible fiscal adjustment can have expansionary effects as the private sector anticipates a lower future tax burden. Moreover, there is some evidence that credible fiscal adjustments may be associated with an expansion, not a contraction, of output, as private sector wealth increases given lower taxes and interest rates, spurring private demand, and increasing output (Alesina and Perotti, 1995, Alesina and Ardagna, 2010, Abbas and others 2013, and Eyraud and Weber 2013).

Building on these elements, we examine the extent to which changes in fiscal policy in sub-Saharan African countries have knock-on effects on output in the short- and mediumterm. In addition, focusing squarely on fiscal consolidation episodes, we estimate the impact 
on output and the role of policies and country characteristics in mitigating the contractionary effects of fiscal consolidations. Empirically, we use forecast errors to identify the causal effects of unanticipated changes in public investment, consumption, and revenues on output growth (Auerbach and Gorodnichenko 2013a, b; and Abiad, Furceri, and Topalova 2016); and the local projections method (Jordà 2005), to trace the short- and medium-term responses of output to the unanticipated changes in different fiscal variables for up to five periods ahead. By examining the design of fiscal adjustments, institutional and country characteristics, and supporting policy environments, we are also able to identify a number of factors and circumstances contributing to the size of fiscal multipliers.

Our analysis builds on and extends the literature in several ways. First, we focus squarely on sub-Saharan Africa to understand the region's experience during periods of commodityrevenue declines and fiscal consolidations. Our analysis is informed by a newly constructed commodity-related revenue database using a variety of sources including data from country authorities. To our knowledge, this is the first analysis estimating fiscal multipliers and the output effects of fiscal consolidations for sub-Saharan Africa as a whole. Second, our empirical formulation allows us to investigate the effects of changes in all three fiscal policy instruments - government consumption, government investment, and revenue-while at the same time distinguishing between their relative impact on growth. This is an important innovation compared to most studies in the literature, which allows the formulation of policy recommendations after examining the impact of each policy variable and based on the identified relative rankings. Third, by identifying episodes of fiscal consolidations in subSaharan Africa for the period 1990-2016 we distinguish between the role of fiscal policy on output and the effects of fiscal consolidation episodes on output. Beyond the fact that, conceptually, the distinction between these two parts is needed-a reduction in investment or an increase in revenues does not necessarily translate into a fiscal consolidation (given that, for instance, a cut in investment can be offset by an increase in consumption of the same amount, leaving the overall fiscal position unchanged) — it is also needed to tailor the analysis to the different economic situation of the countries in sub-Saharan Africa.

Our findings suggest that, overall, estimated fiscal multipliers in sub-Saharan Africa tend to be smaller than those typically identified in advanced or emerging market economies. Looking at the impact of changes in fiscal policy on output suggests that the impact depends critically on whether these changes are expenditure- or revenue- based. Changing government investment by 1 percentage point of GDP changes output in the same direction by about 0.1 percent in the year of implementation, and by about 0.7 percent after three years. Changing public consumption has a smaller effect on output compared to public investment: after three years, a 1 percentage point of GDP change in government consumption results in a 0.5 percent change in output in the same direction.

Fiscal consolidation episodes also give rise to significant short- and medium- term output effects, depending on the type of fiscal measures used. During spending-based fiscal consolidations increasing the cyclically adjusted primary balance by 1 percentage point of GDP decreases output by 0.3 percent on impact, and by 0.4 percent over a three-year horizon. In addition, fiscal consolidations based on reducing public investment have the largest contractionary effect: during these episodes, a 1 percentage point improvement in the 
cyclically adjusted primary balance reduces output by about 0.4 percent on impact and by 0.7 percent after three years. Finally, fiscal consolidations based on cuts in current expenditures have a smaller effect on economic growth (although the effect is statistically insignificant), while fiscal consolidations based on revenue mobilization decrease output less than those based on public investment cuts.

The negative impact on growth can be mitigated through the design of the fiscal adjustment. The precise impact of a change in fiscal policy on output is determined by a range of factors: responses are larger in periods of low growth; and smaller where public expenditure management and revenue administration are more inefficient. In addition, accompanying policies can play an important mitigating role during fiscal consolidations. In particular, contractionary effects can be lessened in the presence of: an accommodative monetary policy stance while keeping inflation in check; greater exchange rate flexibility, where possible; and the existence of solid external buffers and more openness to trade.

The rest of the paper is organized as follows. Section II reviews the data and some stylized facts to set the stage for the remainder of the paper. Section III discusses the empirical methodology used in the paper. Section IV presents the results on the effect of fiscal policy on output. Section V presents the results on the impact of fiscal consolidations on economic activity, and the role of mitigation policies. Section VI concludes with some policy recommendations.

\section{DATA AND StYlized FACTS}

\section{A. Data}

Sub-Saharan Africa has undergone episodes of fiscal adjustments in the past, sometimes prompted by commodity price dips. Currently, the region experiences an environment where commodity exporters are facing a likely long period of low prices which has translated in a substantial decline in commodity-related revenues in many countries. We explore the impact of these commodity-price shocks in the sub-Saharan Africa region by taking a historical perspective on commodity revenue declines over the past four decades or so. Our main sample of analysis covers 44 sub-Saharan African countries, and uses fiscal and other macroeconomic data from the World Economic Outlook Database over the period 19902016. The commodity-related revenue dataset is complemented with data from country authorities, the World Commodity Exporters, and the ICTD Government Revenue Dataset (see Table 1 for definitions of variables and sources).

The analysis on the impact of fiscal policy on economic activity uses vintages of the WEO database to construct the forecast errors of fiscal policy variables as an input in the fiscal multipliers estimations. These forecasts of public investment, public consumption, and fiscal revenue correspond to the WEO staff projections published in October of the same year. The forecast error is calculated as the difference between the actual realization of the fiscal variables and their forecasts in each year.

To identify fiscal consolidation episodes, we rely on fiscal policy indicators from the WEO 
database. We consider "action-based" fiscal consolidations (IMF 2010), that is, improvements in fiscal positions resulting from a reduction in public expenditures or increases in revenue mobilization that are not simply explained by a surge in commodity revenues or a reflection of increases in government revenues associated with improvements in the business cycle. Specifically, (i) we use the cyclically adjusted primary balance (CAPB) and require an improvement in the CAPB of at least 1 percent of GDP (IMF, 2010; Dell'Erba, Koloskova, and Poplawski-Ribeiro, 2014); (ii) exclude episodes that are associated with improvements in commodity revenues (commodity-related revenues did not increase by more than 1 percent of GDP); and (iii) require either a minimum amount of spending cuts (at least 0.5 percent of GDP) or a minimum amount of increases in noncommodity revenues (at least 0.5 percent of GDP). We distinguish episodes depending on whether they are spending-based (those that include a minimum amount of government spending cuts and not associated with improvements in commodity revenues) or revenuebased (those that include a minimum amount of increases in government revenues, not associated with improvements in commodity revenues). In the robustness section, we alter these definitions to check the sensitivity of our results.

The CAPB is defined following the aggregated approach discussed in Fedelino, Horton, and Ivanova 2009 as $C A P B=R^{A d j}-E^{p}$, where $R^{A d j}$ corresponds to the cyclically adjusted revenues, and $E^{p}$ refers to total primary spending. We adjust revenues by the business cycle: $R^{A d j}=\frac{R}{(1+\gamma)}$, where $R \quad$ corresponds to government revenues, and $\gamma$ refers to the estimated output gap. The output gap is estimated using a Hodrick-Prescott filter with a smoothing parameter of 6.25, as proposed by Ravn and Uhlig 2002 and extended with historical data prior to 1990 and five years ahead of World Economic Outlook projections to reduce the end-of-sample bias.

\section{B. Stylized Facts}

Analyzing all episodes of commodity revenue declines during the period 1990-2016 in subSaharan Africa, we observe that, on average, commodity-related revenues declined by 4 percent of GDP and, after a partial offset from non-commodity-related revenues, total government revenues decreased by about 3 percent of GDP (Figure 1). Current and capital spending remained mostly unchanged, with overall fiscal balances deteriorating by about 3 percent of GDP, suggesting difficulties in adjusting to the revenue decline. Overall, the combination of the income shock from lower commodity prices, deteriorating overall balances, and possibly weaker global demand was associated with a growth deceleration of about 1 percentage point of GDP on average. In the emerging and developing economy sample, both the average revenue shock and the growth effect are smaller than in the case of sub-Saharan Africa, perhaps reflecting more diversification.

The average decline in commodity-related revenues was more dramatic for oil-exporting subSaharan African countries (about 5 percentage points of GDP), and was associated with capital spending cuts of about 1 percentage point of GDP, on average. Also in this group, overall deterioration in the fiscal balance was larger, at about 3.2 percent of GDP, and growth decelerated by about 0.6 of a percentage point of GDP. 
In addition to episodes of commodity revenue declines, we analyze the stylized facts of fiscal consolidations across the region during 1990-2016, and quantify their direct impact on economic activity. As discussed before, we characterize cases of fiscal consolidation as episodes during which there were significant improvements in the countries' fiscal positions. During spending-based fiscal consolidation episodes, primary expenditures were reduced by about 3 percent of GDP, on average, in both the sub-Saharan Africa countries and the emerging and developing economies sample (Figure 2).

In both samples, the overall fiscal balance during fiscal consolidation episodes improved by about 2 percent of GDP starting from an average overall fiscal deficit of about 4 percent of GDP. Similarly, the change in the cyclically-adjusted primary balance was about 3 percent in both samples. In terms of composition, cuts in primary expenditures were roughly evenly distributed between capital spending and current primary spending cuts (about 1.7 and 1.5 percent of GDP, respectively), on average in a sub-Saharan African country (Figure 3). In addition, government revenues declined moderately in both samples, possibly as a result of the slowdown in economic activity.

Revenue-based fiscal consolidations not associated with commodity revenue increases were of similar magnitude as those based on spending. They were also characterized by an average improvement in the fiscal position of about 2 percent of GDP, and were mostly explained by improvements in government revenues, with limited cuts in primary expenditures (Figure 4).

Overall, past spending- and revenue-based consolidation episodes were associated with growth slowdowns. During spending-based consolidations growth decelerated by about 0.6 and 0.3 percent of GDP in the sub-Saharan Africa and emerging and developing economy samples, respectively, compared to the rate of growth prior to the consolidation episode. The growth deceleration seems to have been milder in the case of revenue-based fiscal consolidations compared to spending-based adjustments.

\section{EMPIRICAL METHODOLOGY}

\section{A. Estimating Fiscal Multipliers}

To examine the effect of fiscal policy on output, we follow IMF 2013 and Auerbach and Gorodnichenko 2013a, b to identify unexpected changes in fiscal policy (shocks) using forecast errors. This identification strategy overcomes the two issues often associated with the empirical estimation of the effect of fiscal policy on output, namely the fiscal foresight, and the potential feedback from the state of the economy to the fiscal variable (for a discussion see Leeper and others 2013, and Abiad and others 2016).

Output impulse responses after the unanticipated changes in fiscal policy are estimated using the local projections method (LPM) proposed by Jordà 2005 and advocated by Stock and Watson 2007 and Auerbach and Gorodnichenko 2013a, b. The LPM has been widely used in the literature investigating fiscal multipliers. It is viewed as a flexible alternative to the 
typically used vector autoregression (VAR) estimation and it allows the estimation of nonlinearities in impulse responses (for example, under different states of the economy). Also, it does not require order assumptions and quarterly data - which is important in the context of sub-Saharan African countries where quarterly data are not consistently available. We estimate the impact of fiscal policy shocks on economic activity using the following specification:

$$
\begin{gathered}
\frac{Y_{i, t+h}-Y_{i, t-1}}{Y_{i, t-1}}=\alpha_{i}^{h}+\gamma_{t}^{h}+\beta^{I h} S I_{i, t}+\beta^{C h} S C_{i, t}+\beta^{R h} S R_{i, t}+\cdots \\
\sum_{j=1}^{p} \theta_{1, j}^{h} \Delta y_{i, t-j}+\sum_{j=1}^{p} \theta_{2, j}^{h}(I, C, R)_{i, t-j}+\sum_{j=0}^{p} \theta_{3, j}^{h} z_{i, t-j}+\sum_{j=1}^{p} \theta_{4, j}^{h} x_{i, t-j}+\ldots \\
+\sum_{j=0}^{h-1} \theta_{5, j}^{h}(S I, S C, S R)_{i, t+h-j}+\sum_{j=0}^{h-1} \theta_{6, j}^{h} z_{i, t+h-j}+\varepsilon_{i, t}^{h}, \quad \text { (1) }
\end{gathered}
$$

where $i$ and $t$ denote countries and years, respectively, and $h$ is the number of periods ahead for which the multiplier is calculated. The left-hand-side refers to the cumulative growth rate of real GDP at horizon $h$ : for $h=0$, the equation estimates the contemporaneous effect of the fiscal shocks on real GDP, while the effect for each horizon $h=1, \ldots, 5$ is estimated in separate equations. The $\beta$ 's refer to the estimated cumulative response of GDP over time given a shock in public investment, consumption and revenues.

The specification includes country and year fixed effects, the shocks in public investment, public consumption, and fiscal revenue at time $t$ (SI, SC, and SR) divided by the level of GDP in $t-1$ to allow the direct estimation of the relevant multipliers. The three fiscal shocks enter the model simultaneously which allows formal statistical testing of the relative sizes of the respective multipliers by each instrument. The specification is complemented by other control variables which include lags of the rate of growth of real GDP; lags of the fiscal variables, which are predetermined at $t$; contemporary and lagged observations of external variables (denoted by $z$ ) proxied by the changes in commodity terms of trade and the real GDP growth of trading partners; lags of other domestic macroeconomic variables (denoted by $x$ ), such as real money growth and inflation, to proxy monetary policy; and future realizations of the unexpected shocks in the fiscal variables and the exogenous variables (as suggested in Teulings and Zubanov 2014).

The fiscal multiplier representing the cumulative change of real GDP over $h$ periods following a one-unit shock in the fiscal variable is obtained directly from the estimation (unlike multipliers derived from estimated elasticities relating rates of growth of fiscal variables and GDP). For example, the investment multiplier $\beta^{I h}$ is:

$$
\beta^{I h}=\frac{Y_{i, t+h}-Y_{i, t-1}}{Y_{i, t-1}} / \frac{S_{i, t}}{Y_{i, t-1}}
$$




\section{B. Estimating the Effects of Fiscal Consolidations}

We estimate the effect of fiscal consolidations on economic activity using the LPM following recent literature (Dell'Erba, Koloskova, and Poplawski-Ribeiro 2014; Jordà and Taylor 2016; and Devries and others 2011). We estimate the expected impact of the policy intervention relative to a baseline output growth after controlling for domestic and external economic conditions.

The fiscal policy variable introduced in the estimation corresponds to the size of the fiscal consolidation measured by the change in the CAPB. Specifically, following Jordà 2005 and Dell'Erba, Koloskova, and Poplawski-Ribeiro 2014, we estimate the effect of policy intervention $c_{j}$ on the outcome variable $Y$ (at time period $t+h$ ) relative to a baseline $c_{0}$. This is given by $E\left[\left(Y_{t, h}\left(c_{j}\right)-Y_{t}\right)-\left(Y_{t, h}\left(c_{0}\right)-Y_{t}\right)\right]$, and the policy intervention can be calculated by the local projection:

$$
Y_{t+h}-Y_{t}=\alpha^{h}+\beta^{h} C_{t}+\theta^{h} \omega_{t}+\varepsilon_{t+h}
$$

where the fiscal policy variable is $C_{i, t}$ and $\omega_{t}$ is the conditioning set. The expected impact of the policy intervention is equivalent to an impulse response from a VAR:

$$
E\left[\left(Y_{t, h}\left(c_{j}\right)-Y_{t}\right)-\left(Y_{t, h}\left(c_{0}\right)-Y_{t}\right)\right]=\beta^{h}\left(c_{j}-c_{0}\right) \text { for } h=1 \ldots, H .
$$

Specifically, the model to estimate the effect of the policy intervention is described by:

$$
\begin{gathered}
\frac{Y_{i, t+h}-Y_{i, t-1}}{Y_{i, t-1}}=\alpha_{i}^{h}+\gamma_{t}^{h}+\beta \boldsymbol{C}_{i, t}+\cdots \\
\sum_{j=1}^{p} \theta_{1, j}^{h} \Delta y_{i, t-j}+\sum_{j=0}^{p} \theta_{2, j}^{h} z_{i, t-j}+\sum_{j=1}^{p} \theta_{3, j}^{h} x_{i, t-j}+\ldots \\
+\sum_{j=0}^{h-1} \theta_{4, j}^{h} C_{i, t+h-j}+\sum_{j=0}^{h-1} \theta_{5, j}^{h} z_{i, t+h-j}+\varepsilon_{i, t}^{h}, \quad \text { (4) }
\end{gathered}
$$

where $Y_{t}$ refers to real GDP, and $C_{i, t}$ corresponds to the fiscal policy variable. The conditioning set includes lags of real GDP growth and additional controls $z_{t}$ such as the growth of the trading partners, as a proxy for external demand; a country-specific measure of commodity terms of trade; and lags of real money growth and inflation, as a proxy for monetary the policy stance, $x_{t}$. In addition, we include future realizations of the fiscal policy variable and the exogenous variables.

We are also interested in the policies or macroeconomic fundamentals that play a role as mitigating factors when fiscal consolidations are implemented. These policies include monetary conditions, the urgency for the fiscal consolidation, and other elements associated with the external sector such as the degree of exchange rate flexibility, the size of buffers, and the degree of trade integration of the economy.

To incorporate the role of policies, we augment (3) by introducing an interaction term 
between the fiscal policy variable and the other policy variables $\left(S_{t}\right)$ of interest as follows:

$$
Y_{t+h}-Y_{t}=\alpha^{h}+\beta^{h} C_{t}+\mu^{h} C_{t} \times S_{t}+\rho^{h} S_{t}+\theta^{h} \omega_{t}+\varepsilon_{t+h}
$$

The total effect of the fiscal consolidation on economic activity is now given by the term $\beta^{h}+\mu^{h} \times S_{t}$, which depends on the different levels of the state variable $S_{t}{ }^{1}$

\section{The Effect of Fiscal Policy on OUtPut}

\section{A. The Size of the Fiscal Multiplier}

As discussed in the empirical methodology section, we estimate equation (1) for a sample of sub-Saharan African countries over the period 1990-2016. The results suggest that multipliers vary depending on the policy variable. Tracing the effects on output of an unanticipated increase in public investment, consumption, and revenues in the year of the shock $(t=0)$ and the cumulative effect up to five years after the shock in Figure 5, shows that public investment shocks have large and significant effects on economic activity. An unanticipated 1 percentage point of GDP change in public investment affects output by about 0.1 percent in the same direction in the year of the shock. In addition, the effect of a change in public investment on output continues to have effects over time: three years after an unanticipated shock to government investment, output changes by 0.7 percent in the same direction. Estimated multipliers for consumption expenditures have a smaller effect on output than investment multipliers (about 0.5 percent after three years). Finally, changing government revenue does not have a statistically significant effect on output.

Consistent with other studies on developing countries, the magnitude of the estimated multipliers is less than one; the investment expenditure multiplier is the largest in magnitude, followed by the multiplier of public consumption, while the multiplier for revenues not statistically significant. Overall, the estimated multipliers are within the range of multipliers found in the literature for similar groups of countries. For instance, the estimated multiplier for investment expenditure is within the range reported by Ilzetski, Mendoza, and Vegh 2013 and Gonzalez-Garcia, Lemus, and Mrkaic 2013 (Table 2). For consumption expenditure, our estimate is broadly in line with the literature, ranging between 0.1 and 0.3 after two years into the shock. For fiscal revenue, other studies generally report a slightly positive but insignificant multiplier. Formal tests to compare the estimated magnitudes of the three fiscal multipliers show that the public investment multiplier is significantly larger than the other two for most horizons considered. However, the estimated multipliers of public consumption and fiscal revenue are not statistically different (Table 3).

These findings have several implications about the composition of fiscal adjustment. First, reductions in government investment are more harmful for growth than cutting government

\footnotetext{
${ }^{1}$ Standard errors depend on the variances and covariance of the interacted terms and are described by $s d\left(\frac{\partial Y}{\partial C}\right)=$ $\sqrt{\operatorname{Var}\left(\beta^{h}\right)+\operatorname{Var}\left(\mu^{h}\right) \times\left(\mathrm{S}_{\mathrm{t}}\right)^{2}+2 \times \operatorname{Cov}\left(\beta^{h}, \mu^{h}\right) \times\left(\left(\mathrm{S}_{\mathrm{t}}\right)\right.}$
} 
consumption. This may be because lower levels of productive investment imply lower capital accumulation, which has negative effects on potential output for subsequent periods (Dell'Erba, Koloskova, and Poplawski-Ribeiro 2014). While this suggests that cuts in public consumption may be relatively a more favorable option, cutting crucial social spending on health, education, and social safety nets should be protected since reductions in current spending can have a larger negative effect on lower-income households, and could adversely impact longer-term development prospects. Second, given the likely small impact on output, increasing revenue mobilization is less costly than cutting expenditures. Indeed, better domestic revenue mobilization offers substantial potential to achieve fiscal consolidation with a lower cost in terms of output growth. ${ }^{2}$

\section{B. Fiscal Multipliers and Country Characteristics}

Previous studies suggest that the impact of fiscal policy shocks depends crucially on the state of the economic cycle and country characteristics, such as periods of low and high growth and the efficiency of public investment and economic management. ${ }^{3}$ We explore these issues in the context of sub-Saharan Africa by introducing a smooth transition function between states in equation (1) based on the standardized distance between the indicator for a specific country and year and the sample mean (see Auerbach and Gorodnichenko 2013a, b and Dell'Erba, Koloskova, and Poplawski-Ribeiro 2014).

In an environment of low growth and economic slack, an increase in public spending can potentially have a larger impact on economic activity than it would in a context of rapid growth. This is because, at full capacity or in an environment of high growth, an increase in public demand is more likely to crowd out private demand, and leave output unchanged. On the other hand, during periods of low growth or economic slack, a fiscal impulse has more room to translate into an expansion of aggregate demand and output. Indeed, we find that fiscal multipliers are larger during periods of slow growth than during upturns in sub-Saharan African countries. Figure 6 shows the output response three years after a fiscal shock (the horizon at which peak effects are observed). During periods of low growth, public spending multipliers tend to be larger than during periods of high growth, while the revenue multiplier shows a smaller magnitude during periods of low growth.

Inefficiencies in public expenditure management and revenue administration tend to decrease multipliers because they limit the impact of fiscal policy on output. Such inefficiencies may capture weaknesses in governance, public investment management — project selection, implementation, and monitoring - all of which result in a dollar's worth of investment expenditures yielding less than a dollar of effective public capital (Barhoumi and others 2016). Since in a low-efficiency environment only a fraction of public investment is

\footnotetext{
${ }^{2}$ In fact, the region has substantial potential for an increase in revenues. As shown in Chapter 2 of IMF (2017), the average sub-Saharan African country could increase its tax-to-GDP ratio by $3 \frac{1}{2}$ to 5 percentage points-and the potential is larger in oil exporters, which could raise the tax-to-GDP ratio by as much as $81 / 4$ percentage points.

${ }^{3}$ The literature on fiscal multipliers has also discussed the effects on fiscal multipliers of the degree of exchange rate flexibility, the level of public debt, and the degree of openness of the economy (Ilzetzki, Mendoza and Vegh 2013; Batini and others 2014; Mineshima, Poplawski-Ribeiro, and Weber 2014). We expand on this discussion below in the context of fiscal consolidations.
} 
translated into productive capital stock and infrastructure, increased public investment leads to more limited output gains (see Chapter 2 of the October 2014 World Economic Outlook). We proxy inefficiencies and quality of economic management using a composite indicator that combines three aspects of the quality of government from the International Country Risk Guide (ICRG), namely the quality of bureaucracy, control of corruption, and the tradition of law and order. Indeed, sub-Saharan African countries with lower governance quality tend to show smaller multipliers of both public spending and revenue. The results presented in Figure 7 suggest that public spending tends to be relatively less productive when the quality of governance is low, a circumstance that may favor rent-seeking over efficient spending (Keefer and Knack 2007). Similarly, in a context of low governance, quality revenue collection may be hampered.

We also use another proxy for investment inefficiencies based on a hybrid indicator that combines physical and survey-based indicators into a synthetic index of the coverage and quality of infrastructure networks IMF 2015. We find that multipliers of both public investment and consumption expenditure are larger in countries where public investment is most efficient, and lower in countries with low efficiency of public investment. Similarly, the multiplier of fiscal revenue is estimated to be larger when the efficiency of public investment is larger, but these estimates and their differences are not statistically significant (Figure 8)

\section{Robustness}

To examine the robustness of our results we investigate alternative specifications and definitions, including using a different definition of public revenues, an alternative construction of the fiscal shocks and how they are introduced in the model, and a different set of control variables.

The baseline estimation uses general government total public revenue which is the most comprehensive measure available. One criticism may be that total revenue may be influenced by revenue coming from other sources (such as royalties and non-tax sources) and thus it may be less closely related to public revenue policies than, say, a more direct measure like tax revenue. To examine if this makes a difference in the results, we estimate the model using tax revenue instead of total public revenue. ${ }^{4}$ Overall, we find similar results. When considering tax revenues instead of overall revenues, the estimated multipliers after three years (the peak effects) for shocks in public investment and consumption are 0.6 and 0.4 , respectively, both statistically significant.

Forecast errors for public investment, public consumption, and fiscal revenue in the baseline are calculated as the difference between the actual realization of the fiscal variables and their forecasts taken from the WEO projections published in October of the same year. Using the forecasts of the April WEO issue of the same year (rather than the October issue) as a robustness check yields similar results to the baseline model. The multipliers for public

\footnotetext{
${ }^{4}$ These estimates, however, are based on a reduced sample due to the limited availability of tax revenue forecasts in the WEO database.
} 
investment and consumption are 0.5 and 0.2 after three years, respectively, and statistically significant. The revenue multiplier remains negative, small and not statistically significant.

Introducing the three fiscal shocks simultaneously in the specification may raise concerns about whether the shocks are correlated. To address this issue, we estimate the model presented in the baseline using only one fiscal shock at a time to avoid any influence from the other shocks. The results are very similar to the baseline specification: three years after the shock, the estimated multipliers for public investment and consumption are 0.6 and 0.5 , respectively, and are both statistically significant, while the multiplier for public revenue remains insignificant. In addition, we check the correlation between the three shocks when they all enter simultaneously in the specification. Correlations between the shocks in the estimation sample tend are small: -0.05 between shocks in investment and consumption spending, 0.29 between revenue and investment spending and 0.01 between revenue and consumption spending.

Another concern is that the forecast errors used as fiscal shocks are to some extent endogenous to GDP growth surprises occurred the same year. To ensure that our findings are not influenced by this potential reverse causality, we estimate an alternative model in which the shocks in fiscal variables are the residuals from regressions of the forecast errors of the fiscal variables used in the baseline model on forecast errors of GDP. Using this alternative model has no significant effect on the multipliers estimated. The multipliers after three years corresponding to public investment and public consumption are 0.6 and 0.5 , respectively, and are both statistically significant while the multiplier for public revenues is not statistically significant.

Finally, the baseline model includes lags of the rate of growth of GDP and country fixedeffects as control variables which may give raise to a bias when using samples with "small" time dimension. This bias (equal to $1 / t$ ) is more serious for short panels but given our sample (with $t>=27$ ) the fixed effects estimator is likely to perform as least as well as other alternatives. Nevertheless, to examine the robustness of our results we estimate the baseline model excluding the lags of GDP growth rates. The resulting multipliers are similar to the ones in the original model. Multipliers for public consumption and investment reach their peak three years after the shock and their magnitudes are 0.6 and 0.5 , respectively, and both are statistically significant, while the multiplier of public revenues is the same as in the baseline model and statistically insignificant.

\section{Fiscal Consolidations, Economic Activity, ANd the Role of Mitigation POLICIES}

The previous section discussed the size of fiscal multipliers considering fiscal shocks (positive or negative) across all fiscal stances, and how they are affected by the economic cycle and the efficiency of public investment and economic management. We now focus squarely on the effects of fiscal consolidation on economic activity and the policies that can lessen their potentially contractionary effects. 


\section{A. How Much Does Fiscal Consolidation Hurt?}

Focusing first on episodes of fiscal consolidation associated with spending cuts and not related to an improvement in commodity revenues, we find that fiscal consolidations have contractionary effects on economic activity. A 1 percentage point adjustment in the ratio of the CAPB to GDP reduces output by about 0.3 percent on impact and by 0.4 of a percent after three years (Figure 9). ${ }^{5}$

Our analysis suggests that the impact on growth depends on the composition of fiscal consolidation. Consolidations driven by reductions in public investment are the least growthfriendly type of fiscal consolidation: a 1 percentage point of GDP adjustment in the fiscal position during these episodes reduces output by about 0.4 percent on impact, and by close to 0.7 percent after three years (Figure 10). As discussed earlier, this result may be explained by the fact that lower investment affects potential output and through this channel has a longerlasting impact on output (Dell'Erba, Koloskova, and Poplawski-Ribeiro 2014).

Considering fiscal consolidations driven by cuts in current expenditures, we find small and insignificant effects on output. This suggests that cutting potentially wasteful components of spending and streamlining expenditures (such as eliminating fuel subsidies which tend to be regressive) may achieve fiscal consolidation and at the same time have only mild or negligible effects on economic activity. Importantly, assessments of the distributional effect of the composition of fiscal consolidation (see for instance, Ball and others, 2013 and Woo and others, 2013), underscore the need to protect crucial social spending on health, education, and social safety nets.

Finally, fiscal consolidations driven by increases in revenue mobilization (and not associated with higher commodity-related revenues) have negative effects on growth, but these are of a smaller magnitude than investment-based fiscal consolidations. A 1 percent of GDP improvement in the fiscal position during these episodes reduces output by about 0.2 percent on impact and by 0.3 percent after three years (although not statistically different from zero) compared to 0.4 and 0.7 , respectively, when fiscal consolidations are investmentbased. As mentioned earlier, in the case of sub-Saharan Africa, the relatively low tax ratios and the untapped potential for revenue mobilization may be a possible explanation for revenue-based measures being less contractionary than investment-based consolidations (see Gaspar, Jaramillo, and Wingender, 2017 for a similar argument). ${ }^{6}$ Indeed, the estimated impact of tax-based consolidations for different levels of tax-to-GDP ratios is smaller in countries with low levels of tax revenue mobilization (Figure 11).

\footnotetext{
5 These results are robust to alternative definitions of fiscal consolidation episodes, as discussed in the robustness section.

${ }^{6}$ For a sample of 15 advanced economies which tend to have larger tax ratios, IMF 2010 finds that tax-based consolidations are more contractionary than spending-based adjustments. Similarly, for a sample of advanced economies, and using a nonlinear estimation, Dell'Erba, Koloskova, and Poplawski-Ribeiro 2014 find that over the medium-term expenditure-based fiscal consolidations are less contractionary than revenue-based consolidations during normal periods of economic growth and not statistically different from each other in the case of prolonged recessions.
} 


\section{B. The Role of Policies and Macroeconomic Factors}

Can policies or macroeconomic fundamentals play a mitigating role when fiscal consolidation is needed? These policies may include the monetary stance, the urgency for the fiscal consolidation and its composition, and other elements associated with the external sector such as the degree of exchange rate flexibility, the size of external buffers, and the degree of trade integration of the economy. To address this point, we augment the baseline specification with an interaction term between the fiscal policy variable and the other accompanying policies and calculate the marginal effect of fiscal consolidation on economic activity for different levels of the policy variables, as described in equation (5).

A more accommodating monetary policy stance, proxied by the rate of growth of broad money and credit to the private sector - or more broadly, less tight liquidity conditionshelps lessen the contractionary effects of fiscal consolidation on growth (Figure 12). We also find preliminary evidence that in countries experiencing higher inflation levels, fiscal consolidation may be less harmful for growth, although these results are not always statistically significant. A plausible channel is that fiscal consolidation reduces aggregate demand, contributing to a reduction in inflation, which in itself is favorable for growth. In addition, if the fiscal consolidation contributes to reducing inflation, it also contributes to strengthening the credibility of the economic policy package that also supports growth.

The contractionary effects of fiscal consolidation are smaller in the case of countries with higher debt (Figure 13). As in the case of high inflation, fiscal consolidation can favor the reduction of high debt levels, as well as have positive credibility and confidence effects, and contribute to reducing the burden of debt service in the future, which in turn allows for freeing resources for productive and growth-friendly investments.

Consistent with the literature on fiscal multipliers (for example, Ilzetzki, Mendoza, and Vegh 2013), we find preliminary evidence that more exchange rate flexibility can lessen the negative impact of fiscal consolidation on economic activity, although the results are not statistically significant (Figure 14). The main channel of transmission is that in a more flexible exchange rate regime, monetary policy is less constrained by fiscal policy, and in the context of a fiscal consolidation it does not need to contract the monetary policy stance, as would be the case in a more rigid exchange rate arrangement.

The analysis also finds evidence that countries with more robust external buffers - measured as the level of international reserves as a percentage of GDP - seem to face a smaller impact of fiscal consolidation on growth. A possible explanation is that, all else being equal, these countries may have greater leeway to implement the fiscal adjustment than a country with exhausted external buffers. Finally, consistent with the fiscal multiplier literature, we find preliminary evidence that growth in more open economies suffers less during fiscal consolidations than in more closed countries. A possible channel is that external demand plays a larger role in overall economic activity in more open economies, making it less dependent on the role of public demand. 


\section{Robustness}

The results on the impact of fiscal consolidations are robust to several robustness tests, including using alternative definitions of fiscal consolidation episodes and testing for the exogeneity of the episodes of fiscal consolidations to the state of the economic cycle. Fiscal consolidation episodes identified in the baseline estimation required an improvement in the CAPB of at least 1 percentage point of GDP not associated with an increase in commodity-revenues. Using different thresholds to identify the episodes of fiscal consolidations does not change the conclusions of our analysis. For example, defining "large" fiscal consolidations as episodes when there is an improvement in the CAPB larger than 1.5 percent of GDP (as in IMF 2010) leads to similar results as the ones presented in the baseline specification although the contractionary effects on output seem to be slightly larger (Figure 15.B).

In addition, the literature has discussed the possibility that the so-called "stop-and-go" fiscal consolidations may have different effects on output than multi-year fiscal adjustments (see Alesina et al. 2013). We explore this issue by identifying fiscal consolidations that are "sustained" over time, defined as fiscal consolidations where the three-year cumulative change in the CAPB was larger than 2.5 percent of GDP, in addition to not being associated with an increase in commodity-revenues as in the baseline specification. The results suggest that sustained fiscal consolidations are associated with stronger contractionary effects on economic activity (Figure 15.C). We also define spending-based consolidations using the same criteria as in the baseline (i.e. a minimum decline in spending of 0.5 percent of GDP and an improvement in the CAPB of at least 1 percentage point of GDP) but, additionally, require that there is a larger component of spending cuts than revenue increases. Only a few of the episodes identified in the baseline, where decreases in spending played a role in the improvement in the CAPB, also experienced a revenue mobilization effort that matched the cuts in spending. Excluding these events form the estimation yields very similar results as in the baseline (Figure 15.D).

Following Dell'Erba, Koloskova, and Poplawski-Ribeiro 2014 we estimate country-bycountry regressions to test for the exogeneity of the identified episodes. We regress the consolidation episodes' variable on two lags of real GDP growth and the debt to GDP ratio. In the case of two countries in the sample the coefficients were not statistically equal to zero (F-test). Dropping these two countries from the sample yields similar results to the baseline specification (Figure 15.E).

Finally, we examine whether the results are driven by a specific country. We follow Dell'Erba, Koloskova, and Poplawski-Ribeiro 2014 and re-run the baseline specification excluding one country at the time at each estimation. The results from this exercise remain broadly in line with the results presented in the baseline specification. For instance, the average decline on growth after a one percentage point increase in the cyclically-adjusted primary balance after a spending-based consolidation is of 0.3 on impact and 0.2 after 3years, relative to 0.3 and 0.4 in the baseline specification (Figure 15.F). 


\section{Conclusions}

Our results suggest that fiscal consolidations in sub-Saharan African countries typically have a contractionary effect on output. The composition of fiscal consolidation also matters: cutting capital expenditures is much costlier in terms of output than cutting current expenditures or raising revenue. During episodes of investment- based fiscal consolidation, a 1 percentage point of GDP improvement in the fiscal position lowers output by 0.4 percent in the first year of consolidation, and by about 0.7 percent three years later. In contrast, during fiscal consolidations based on current expenditures and revenue, a 1 percentage point of GDP improvement in the fiscal position lowers output on impact by 0.1 and 0.2 percent, respectively.

This suggests that countries in the region facing the urgent need to consolidate will need to implement policies that are likely to weigh negatively on economic activity. ${ }^{7}$ At the same time, they face difficult choices about the timing and speed of consolidation and what instruments to use. What can be done to mitigate the negative impact of consolidation on growth? Can fiscal positions be improved while finding a way to exert a more limited effect of consolidation on output? Our analysis suggests the following in response:

First, since increasing revenue is less costly in terms of output, consolidation through revenue mobilization is preferable to cutting expenditures, especially public investment. Furthermore, increasing revenue through domestic revenue mobilization can yield substantial returns by allowing for addressing the region's social and infrastructure gaps. Since tax collection in the region is generally low, increasing revenue mobilization can be growth enhancing (Gaspar and others, 2017). Indeed, there is scope to further boost public revenues through the expansion of tax bases and the modernization of outdated tax structures, and by increasing tax rates. Estimates for the region suggest a large untapped revenue potential: on average, sub-Saharan Africa countries could increase their tax-to-GDP ratio between 3.5 and 5 percentage points. Nonetheless, increases in revenue mobilization may be difficult to implement quickly, creating a need to adjust spending in the short term.

Second, cutting current expenditure is preferable to cutting investment but here, too, composition matters. Options include streamlining expenditures by containing the wage bill in oversized public sectors, and eliminating highly regressive and poorly targeted fuel subsidies in favor of targeted social spending. Current spending cuts are likely to have social costs and hence need to be designed in conjunction with social protection schemes and the preservation of crucial social spending on health and education. Cutting capital expenditures, which arguably tends to encounter the least resistance, should be the last option and limited to items that have a limited impact on domestic activity (for example, those with a large import component) and long-term economic growth, or in cases where the scaling-up of investment has taken place and consolidation is urgent. In addition, capital expenditures

\footnotetext{
${ }^{7}$ Some related literature discusses a tradeoff between consolidation and growth, in effect slowing the accumulation of debt to control its possible negative effect on growth, on the one hand, and the risk that consolidation may slow down growth, on the other. For example, DeLong and Summers $2012 \mathrm{f}$ suggest that fiscal consolidation and austerity may be self-defeating if they cause short-term reductions in growth to become permanent through negative hysteresis effects on trend output.
} 
could be stream- lined following a quality-based prioritization of projects, as fiscal multipliers are smaller where spending efficiency is low.

Finally, complementary policies can play an important mitigating role in fiscal consolidation. A more accommodative monetary policy, while keeping inflation in check, can lessen the contractionary effects of fiscal consolidation by offsetting some of the negative demand effects. In addition, greater exchange rate flexibility wherever possible, and greater openness to trade may play a mitigating role. Building external buffers in the form of international reserves and creating fiscal space through the establishment of credible medium-term fiscal frameworks and fiscal rules, can go a long way in preventing the need for abrupt fiscal consolidations in the future. 


\section{References}

Abbas, A., B. Akitoby, J. Andritzky, H. Berger, T. Komatsuzaki, and J. Tyson. 2013. "Dealing with High Debt in an Era of Low Growth." IMF Staff Discussion Note 2013/07, International Monetary Fund, Washington, DC.

Abiad, A., D. Furceri, and P. Topalova. 2016. "The Macroeconomic Effects of Public Investment: Evidence from Advanced Countries." Journal of Macroeconomics 50: 224-40.

Alesina, A. and R. Perotti. 1995. "Fiscal Expansions and Fiscal Adjustments in OECD Countries.” Economic Policy, 10 (21): 205-248.

Alesina, A.and S. Ardagna. 2010. "Large Changes in Fiscal Policy: Taxes versus Spending." In Tax Policy and the Economy, edited by J. R. Brown. Cambridge, MA: National Bureau of Economic Research.

Alesina, A., C. Favero and F. Giavazzi .2013. "The Output Effect of Fiscal Consolidations." IGIER Working Papers No. 478, (Milan: Innocenzo Gasparini Institute for Economic Research, Bocconi University).

Auerbach, A., and Y. Gorodnichenko. 2013a. "Fiscal Multipliers in Recession and Expansion." In Fiscal Policy After the Financial Crisis, edited by A. Alesina and F. Giavazzi. Cambridge, MA: National Bureau of Economic Research.

. 2013b. "Measuring the Output Responses to Fiscal Policy." American Economic Journal: Economic Policy 4 (2): 1-27.

Ball, L., Furceri, D., Leigh, D. and Loungani, P. 2013. "The Distributional Effects of Fiscal Consolidation.” IMF Working Paper 13/151, International Monetary Fund, Washington, DC.

Barhoumi, K., F. Yang, M. Newiak, and H. Vu. 2016. "Public Investment in WAEMU: An Empirical Investigation.” IMF Article IV Staff Report, Selected Issues Paper, International Monetary Fund, Washington, DC.

Barro, R., and H. Grossman. 1971. "A General Disequilibrium Model of Income and Employment." American Economic Review 61(1): 82-93.

Batini, N., L. Eyraud, L. Forni, and A. Weber. 2014. "Fiscal Multipliers: Size, Determinants, and Use in Macroeconomic Projections." IMF Technical Note and Manual No. 2014/04, International Monetary Fund, Washington, DC.

Baum, A., M. Poplawski-Ribeiro, and A. Weber. 2012. "Fiscal Multipliers and the State of the Economy." IMF Working Paper 12/286, International Monetary Fund, Washington, DC.

Blanchard O., and D. Leigh. 2013. "Growth Forecast Errors and Fiscal Multipliers." American Economic Review 103(3): 117-20. 
Dell'Erba, S., K. Koloskova, and M. Poplawski-Ribeiro. 2014. "Medium-term Fiscal Multipliers during Protracted Recessions.” IMF Working Paper 14/213, International Monetary Fund, Washington, DC.

DeLong J B., and L. H. Summers. 2012. "Fiscal Policy in a Depressed Economy." Brookings Papers on Economic Activity, The Brookings Institution, Washington, DC.

Devries, P., Guajardo, J., D. Leigh, and A. Pescatori. 2011. "An Action-based

Analysis of Fiscal Consolidation in OECD Countries.” IMF Working Paper No. 11/128, International Monetary Fund, Washington, DC.

Eyraud, L. and A. Weber. 2013. "The Challenge of Debt Reduction during Fiscal Consolidation.” IMF Working Paper 13/67, International Monetary Fund, Washington, DC.

Fedelino, A., M. Horton, and A. Ivanova. 2009. “Computing Cyclically Adjusted Balances and Automatic Stabilizers." IMF Technical Note and Manual 09/05, International Monetary Fund, Washington, DC.

Gaspar, V., L. Jaramillo and P. Wingender. 2017. "Tax Capacity and Growth: Is there a Tipping Point?" IMF Working Paper 16/234, International Monetary Fund, Washington, DC.

Gonzalez-Garcia, J., Lemus, and M. Mrkaic. 2013. "Fiscal Multipliers." In The Eastern Caribbean Economic and Currency Union: Macroeconomics and Financial Systems, edited by A. Schipke, A. Cebotari, and N. Thacker. Washington, DC: International Monetary Fund.

Gupta, S., B. Clements, E. Baldacci, and C. Mulas-Granados. 2005. "Fiscal Policy, Expenditure Composition, and Growth in Low-Income Countries." Journal of International Money and Finance 24: 441-63.

Ilzetzki, E. 2011. "Fiscal Policy and Debt Dynamics in Developing Countries.” Policy Research Working Paper 5666, World Bank, Washington, DC.

Ilzetzki, E., E. Mendoza, and C. Vegh. 2013. "How Big (Small?) Are Fiscal Multipliers?" Journal of Monetary Economics 60: 239-54.

International Monetary Fund. 2010. "From Stimulus to Consolidation: Revenue and Expenditure Policies in Advanced and Emerging Economies." Fiscal Affairs Department Paper, Washington, DC.

. 2013. "Energy Subsidy Reform in Sub-Saharan Africa: Experiences and Lessons.” African Department Paper, Washington, DC.

. 2014. "Is it Time for an Infrastructure Push? The Macroeconomic Effects of Public Investment," Chapter 3 in World Economic Outlook, (Washington, October), pp. 75114. 
. 2015. "Making Public Investment More Efficient." Policy Paper, International Monetary Fund, Washington DC.

Jordà, Ò. 2005. "Estimation and Inference of Impulse Responses by Local Projections." American Economic Review 95(1): 161-82.

, and A. M. Taylor. 2016. "The Time for Austerity: Estimating the Average Treatment Effect of Fiscal Policy." The Economic Journal 126(590): 219-55.

Keefer, P., and S. Knack. 2007. "Boondoggles, Rent-Seeking, and Political Checks and Balances: Public Investment under. Unaccountable Governments." Review of Economics and Statistics 89(3): 566-72.

Leeper, E. M., T. B. Walker, and S.-C.S. Yang. 2013. "Fiscal Foresight and Information FLows." Econometrica 81 (3): 1115-45.

Mineshima, A., M. Poplawski-Ribeiro, and A. Weber. 2014. "Size of Fiscal Multipliers." In Post-Crisis Fiscal Policy, edited by C. Cottarelli, P. Gerson, and A. Senhadji. Cambridge, MA: MIT Press.

Ravn, M., and H. Uhlig. 2002. "On Adjusting the Hodrick-Prescott Filter for the Frequency of Observations." The Review of Economics and Statistics 84(2): 371-75.

Stock, J., and M. Watson. 2007. "Why Has U.S. Inflation Become Harder to Forecast?" Journal of Money, Credit and Banking 39(1): 13-33.

Teulings, C., and N. Zubanov. 2014. "Is Economic Recovery a Myth? Robust Estimation of Impulse Responses." Journal of Applied Econometrics: 29: 497-514.

Woo, J., Bova, E., Kinda, T. and Zhang, Y.S. 2013. "Distributional Consequences of Fiscal Consolidation and the Role of Fiscal Policy: What Do the Data Say?", IMF Working Paper 13/195, International Monetary Fund, Washington, DC. 


\section{Figures and Tables}
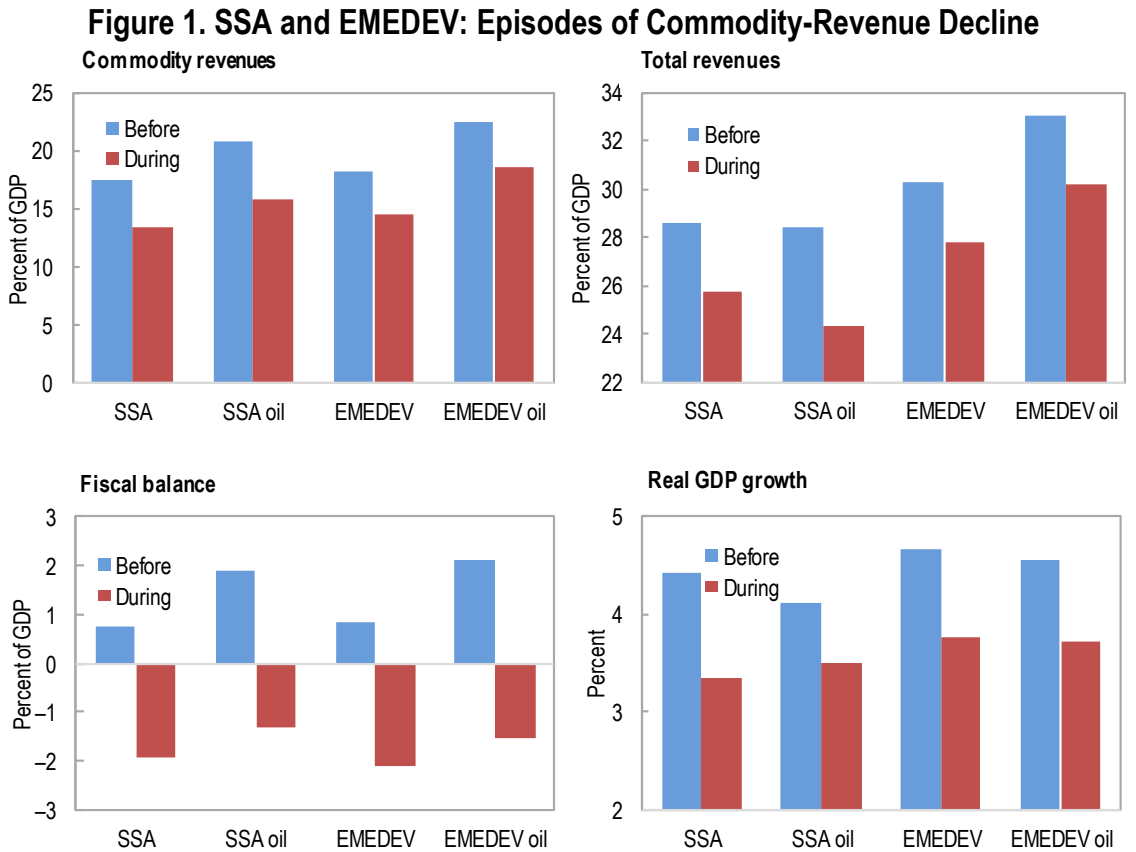

Sources: IMF, World Economic Outlook database; and IMF staff calculations.

Note: "Before" refers to the average values two years prior to the consolidation episode, and "During" refers to the year of the commodityrevenue decline. EMEDEV= all emerging market and developing economies; SSA= sub-Saharan Africa.

\section{Figure 2. SSA and EMEDEV: Spending-Based Fiscal Consolidation Episodes}
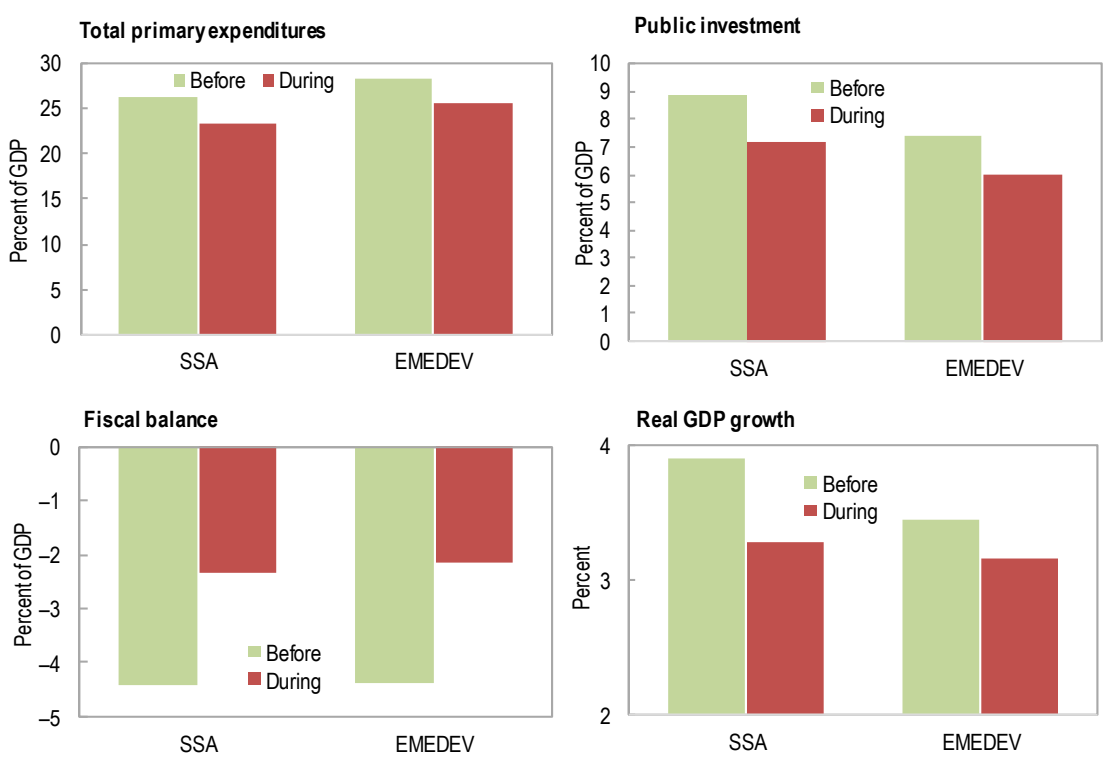

Sources: IMF, World Economic Outlook database; and IMF staff calculations.

Note: "Before" refers to the average values two years prior to the consolidation episode, and "During" refers to the year of the consolidation. EMEDEV = all emerging market and developing economies; SSA = sub-Saharan Africa. 
Figure 3. Change in the Overall Fiscal Balance and Components: Spending-Based Fiscal Consolidation Episodes

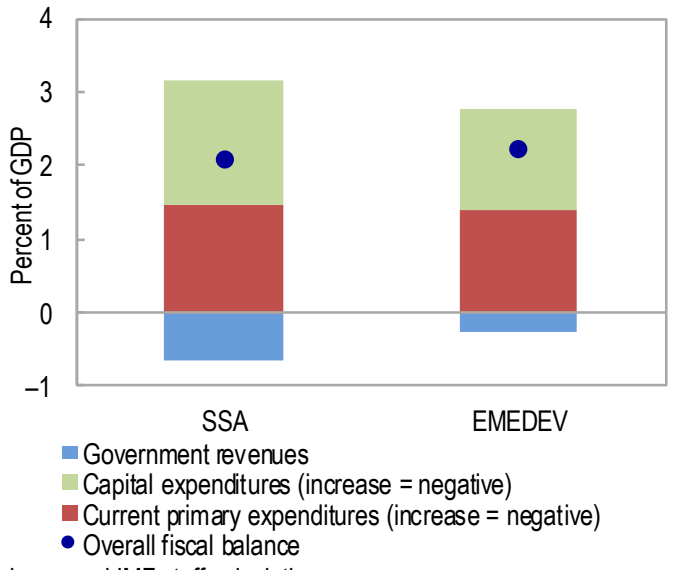

Sources: IMF, World Economic Outlook database; and IMF staff calculations.

Note: EMEDEV = all emerging market and developing economies; SSA = sub-Saharan Africa.

Figure 4. SSA and Emerging and Developing Countries: Revenue-Based Fiscal Consolidation Episodes
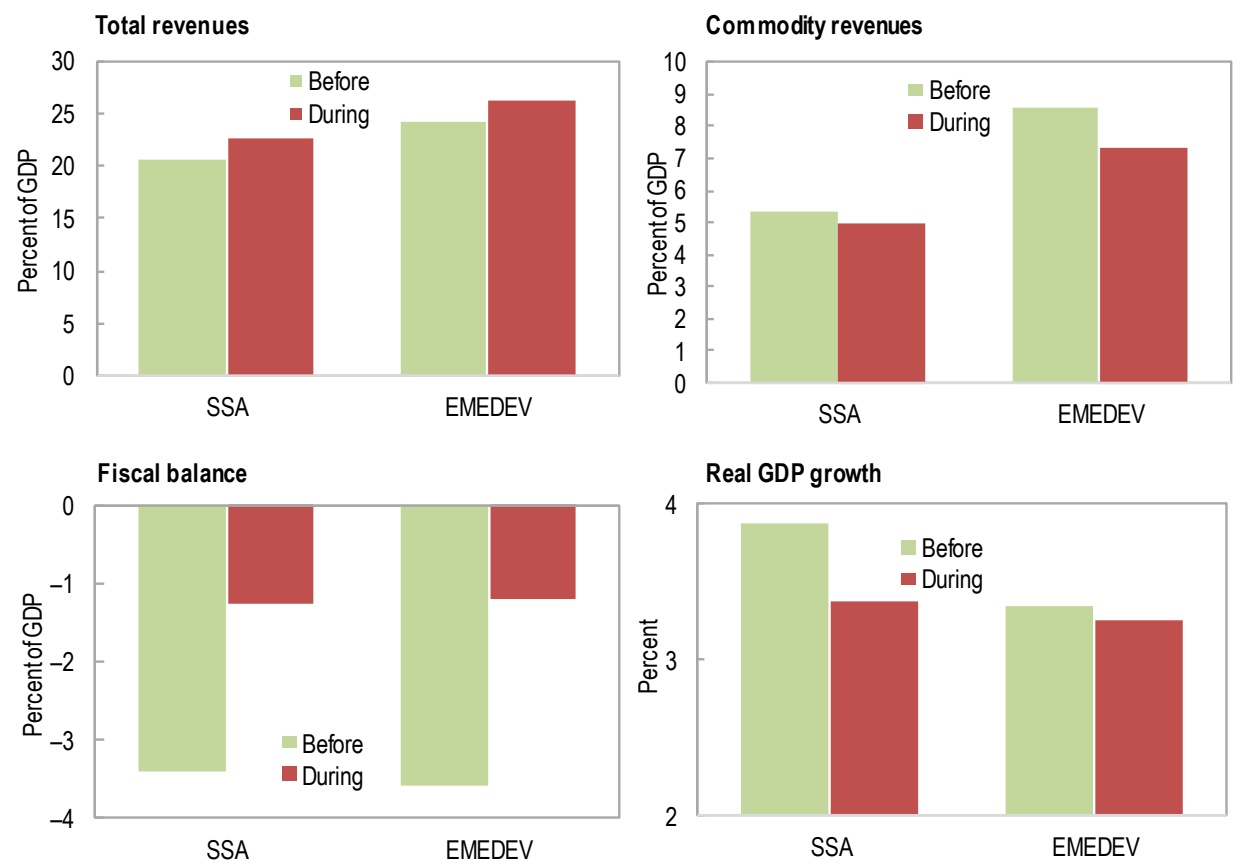

Sources: IMF, World Economic Outlook database; and IMF staff calculations.

Note: "Before" refers to the average values two years prior to the consolidation episode, and "During" refers to the year of the consolidation. EMEDEV = all emerging market economies and developing economies; SSA = sub-Saharan Africa. 
Figure 5. SSA: Effect of Fiscal Policy on Output
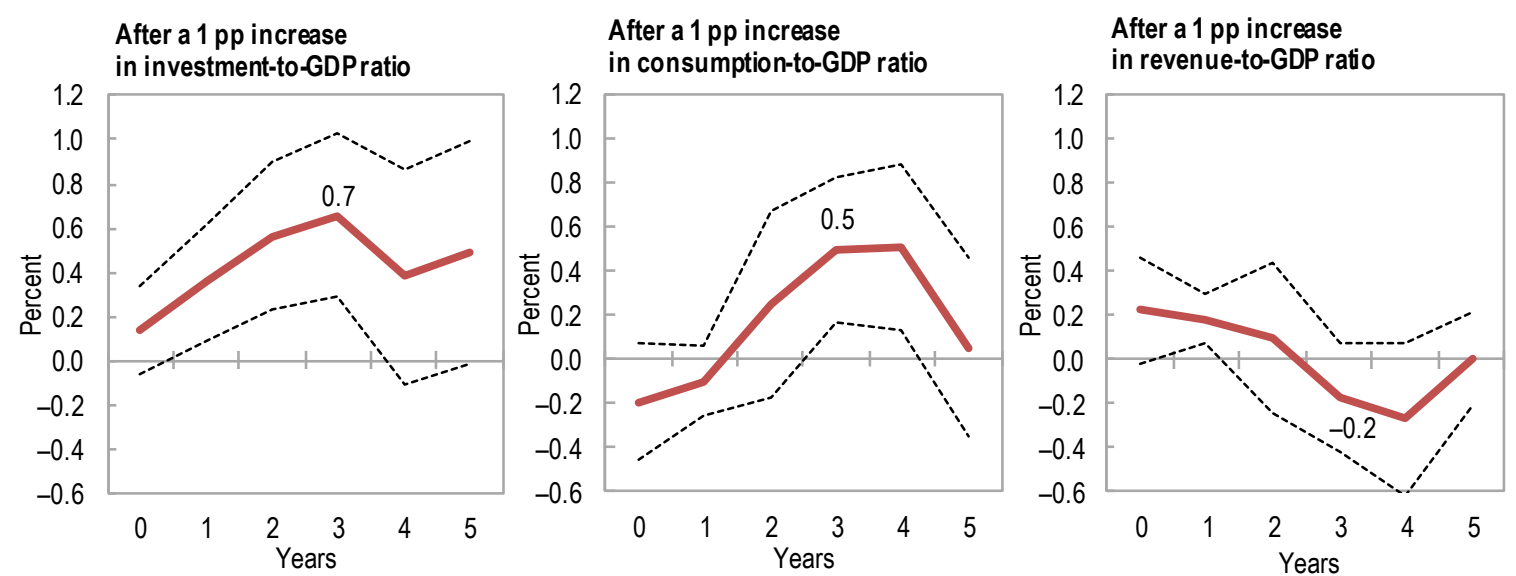

Sources: IMF, World Economic Outlook database; and IMF staff calculations.

Note: The figures present the response in output after a percentage point increase in the ratios of investment, consumption, and government revenues to GDP. Dashed lines indicate 90 percent confidence bands. $p p=$ percentage point.

Figure 6. SSA: Fiscal Multipliers During Periods of High and Low Growth
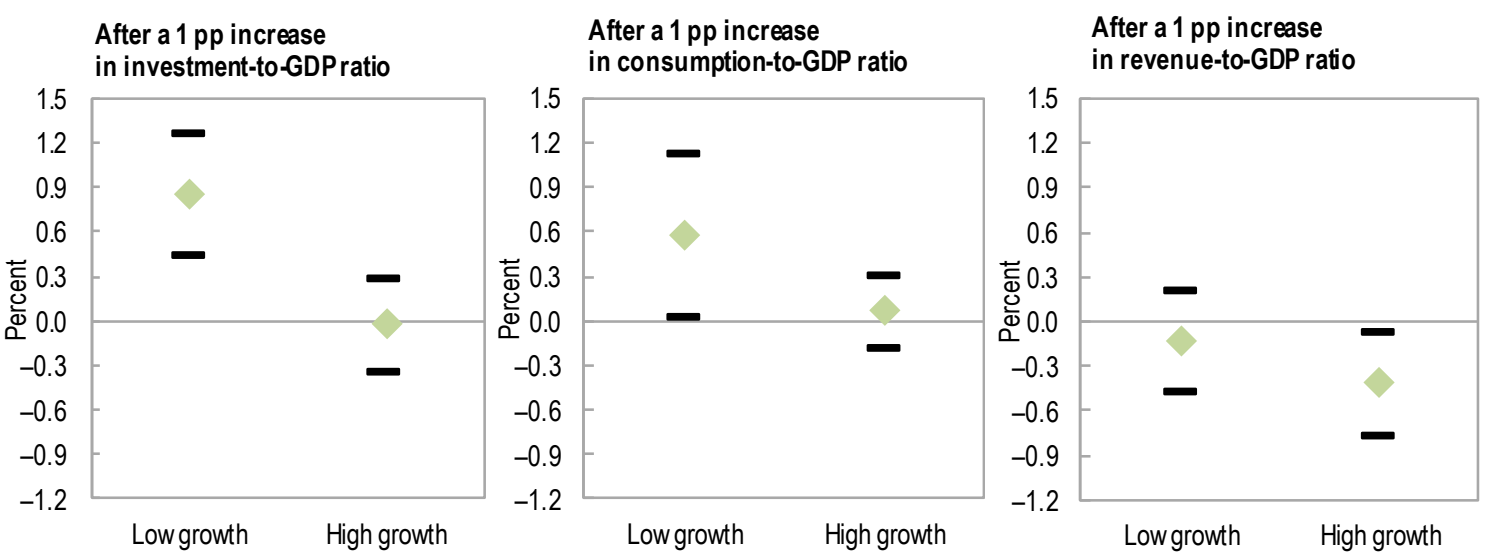

Sources: IMF, World Economic Outlook database; and IMF staff calculations.

Note: The figures present the response in output after a percentage point increase in the ratios of investment, consumption, and government revenues to GDP. Lines indicate 90 percent confidence bands. $p p=$ percentage point.

Figure 7. SSA: Fiscal Multipliers During Periods of High and Low Governance Quality
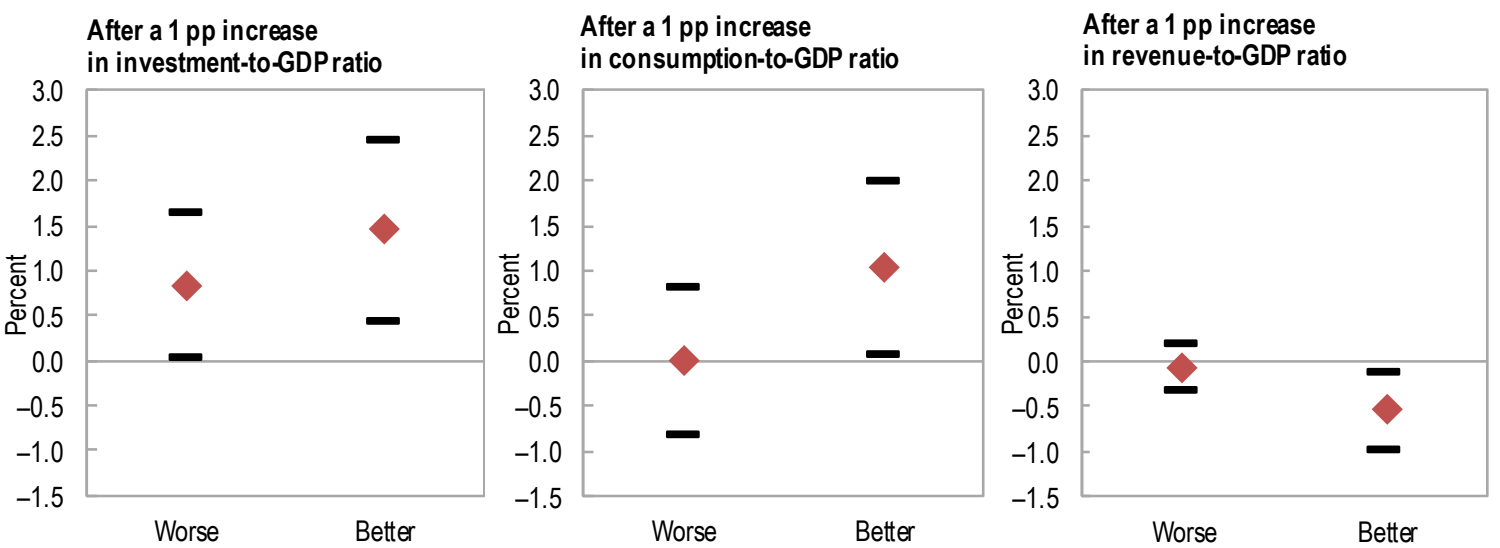

Sources: PRS Group, International Country Risk Guide database; and IMF staff calculations.

Note: The figures present the response in output after a percentage point increase in the ratios of investment, consumption, and government revenues to GDP. Lines indicate 90 percent confidence bands. $p p=$ percentage point. 
Figure 8. SSA: Fiscal Multipliers During Periods of High and Low Efficiency of Public Investment
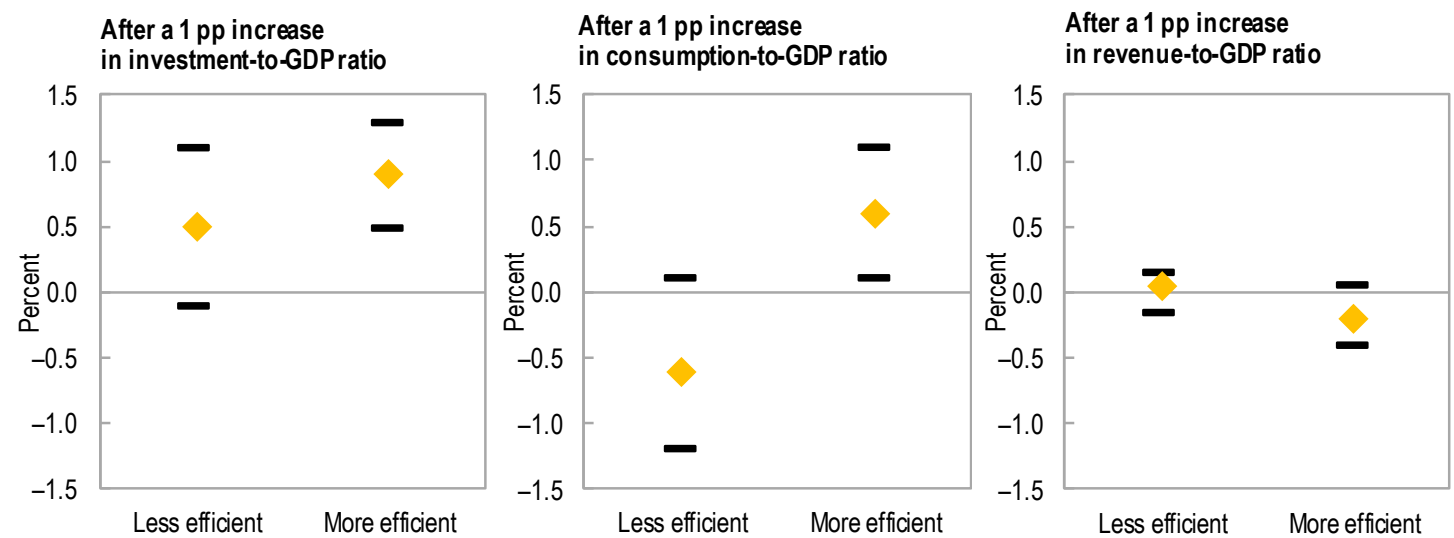

Sources: IMF, Fiscal Affairs Department, Public Investment Efficiency Indicator database; and IMF staff calculations.

Note: The figures present the response in output after a percentage point increase in the ratios of investment, consumption, and government revenues to GDP. Lines indicate 90 percent confidence bands. pp = percentage point.

Figure 9. SSA: Impact of Spending-Based Fiscal Consolidation on Economic Activity

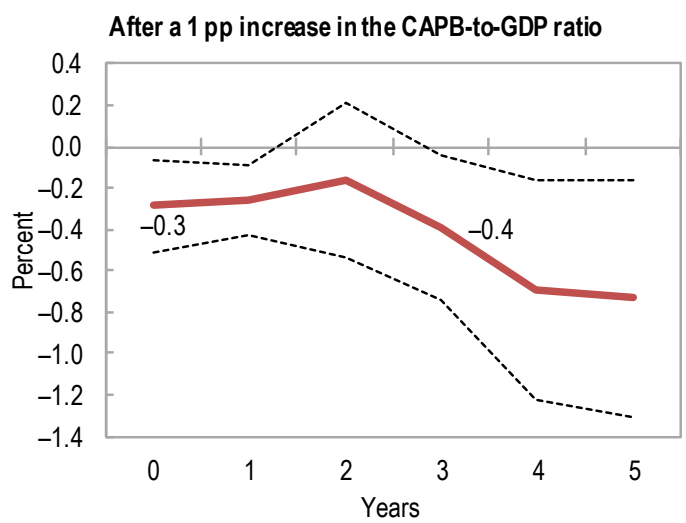

Sources: IMF, World Economic Outlook database; and IMF staff calculations.

Note: The figure presents the response in output after a 1 percentage point to GDP improvement in the cyclically adjusted primary balance (CAPB), following a spending-based consolidation. Dashed lines indicate 90 percent confidence bands. pp= percentage point.

Figure 10. SSA: Impact of Investment, Consumption, and Revenue-Based Consolidations on Output
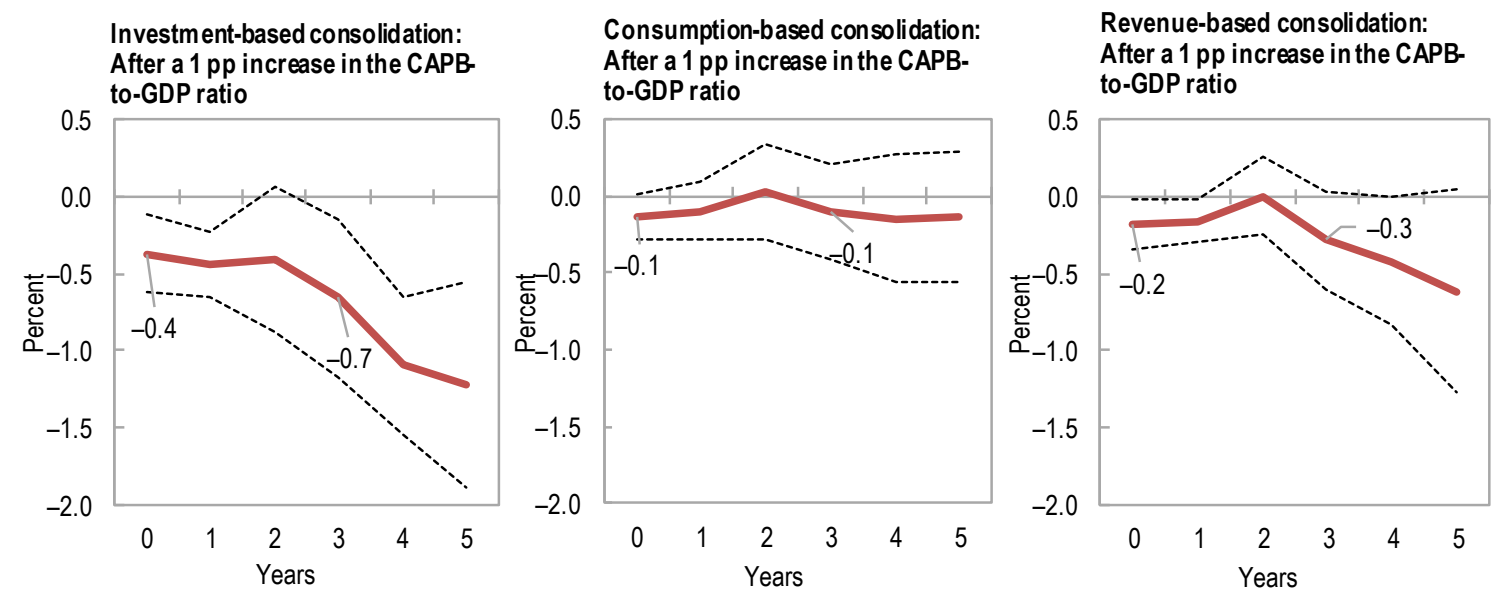

Sources: IMF, World Economic Outlook database; and IMF staff calculations.

Note: The figures present the response in output after a 1 percent of GDP improvement in the cyclically adjusted primary balance (CAPB), following an investment, consumption, or revenue-based consolidation. Dashed lines indicate 90 percent confidence bands. $p p=$ percentage point. 
Figure 11. SSA: Impact of Tax-Based Consolidation on Economic Activity At different levels of tax revenue-to-GDP ratio

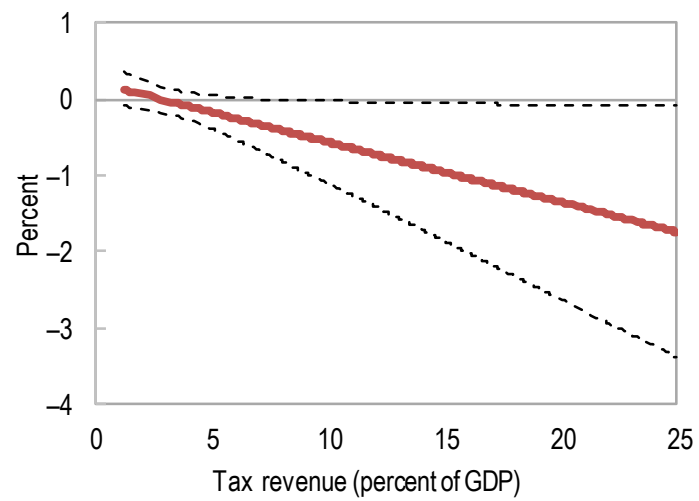

Sources: IMF, World Economic Outlook database; and IMF staff calculations.

Note: The figure presents the marginal effect on output for different levels of the tax-revenue-to-GDP ratio following a tax-based fiscal consolidation. Dashed lines indicate 90 percent confidence bands.

Figure 12. SSA: Impact of Fiscal Consolidations Under Different Monetary Conditions
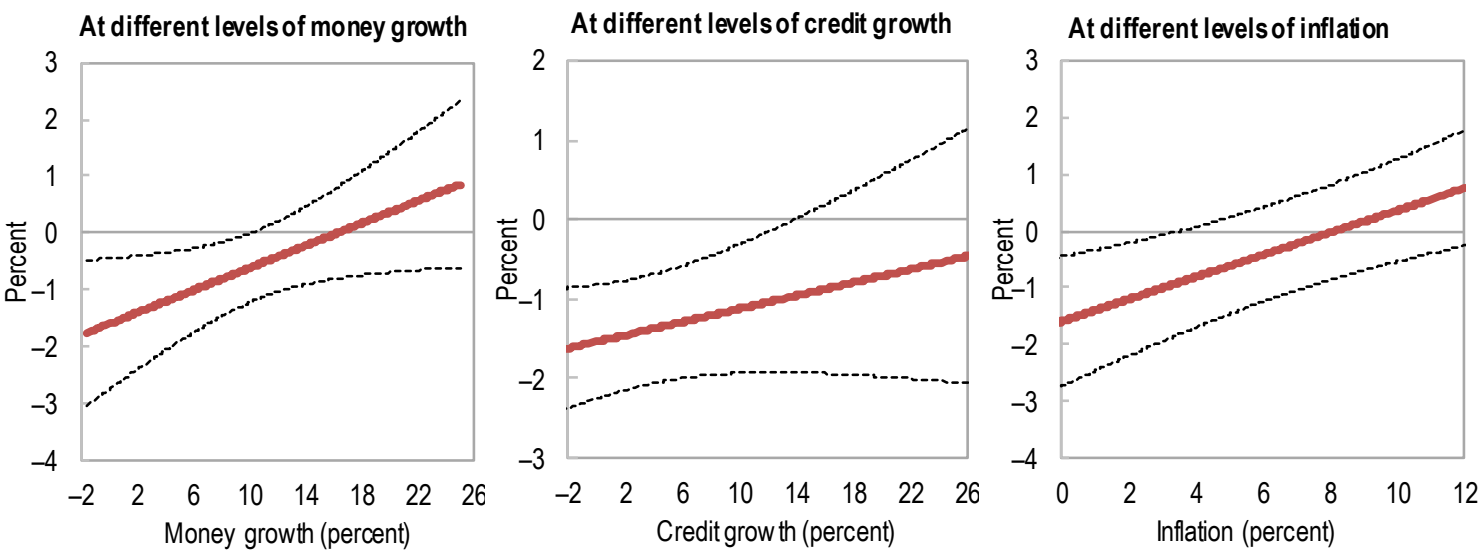

Sources: IMF, International Financial Statistics database; and IMF staff calculations.

Note: The figures present the marginal effect on output for different levels of money growth, credit growth, and inflation following a spending-based fiscal consolidation. Dashed lines indicate 90 percent confidence bands.

Figure 13. SSA: Impact of Fiscal Consolidations in Different Debt Environments
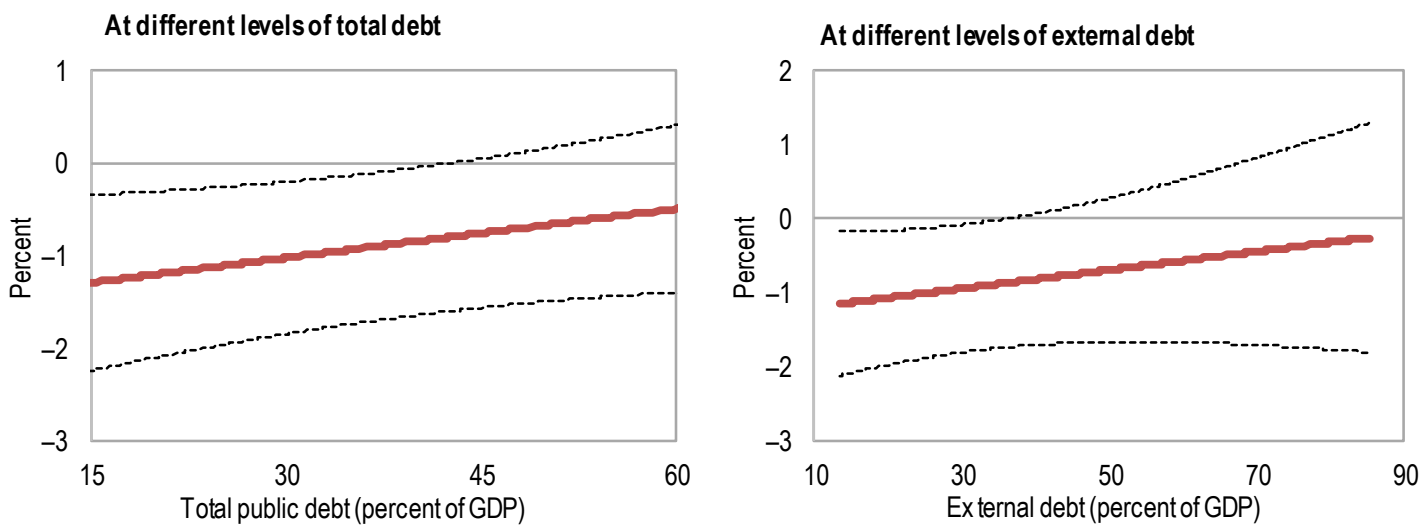

Sources: IMF, World Economic Outlook database; and IMF staff calculations.

Note: The panels present the marginal effect on output for different levels of total and external debt following a spending-based fiscal consolidation. Dashed lines indicate 90 percent confidence bands.

\section{CInternational Monetary Fund. Not for Redistribution}


Figure 14. SSA: Impact of Fiscal Consolidations and Role of Exchange Rate Flexibility, International Reserves Buffers, and Openness to Trade
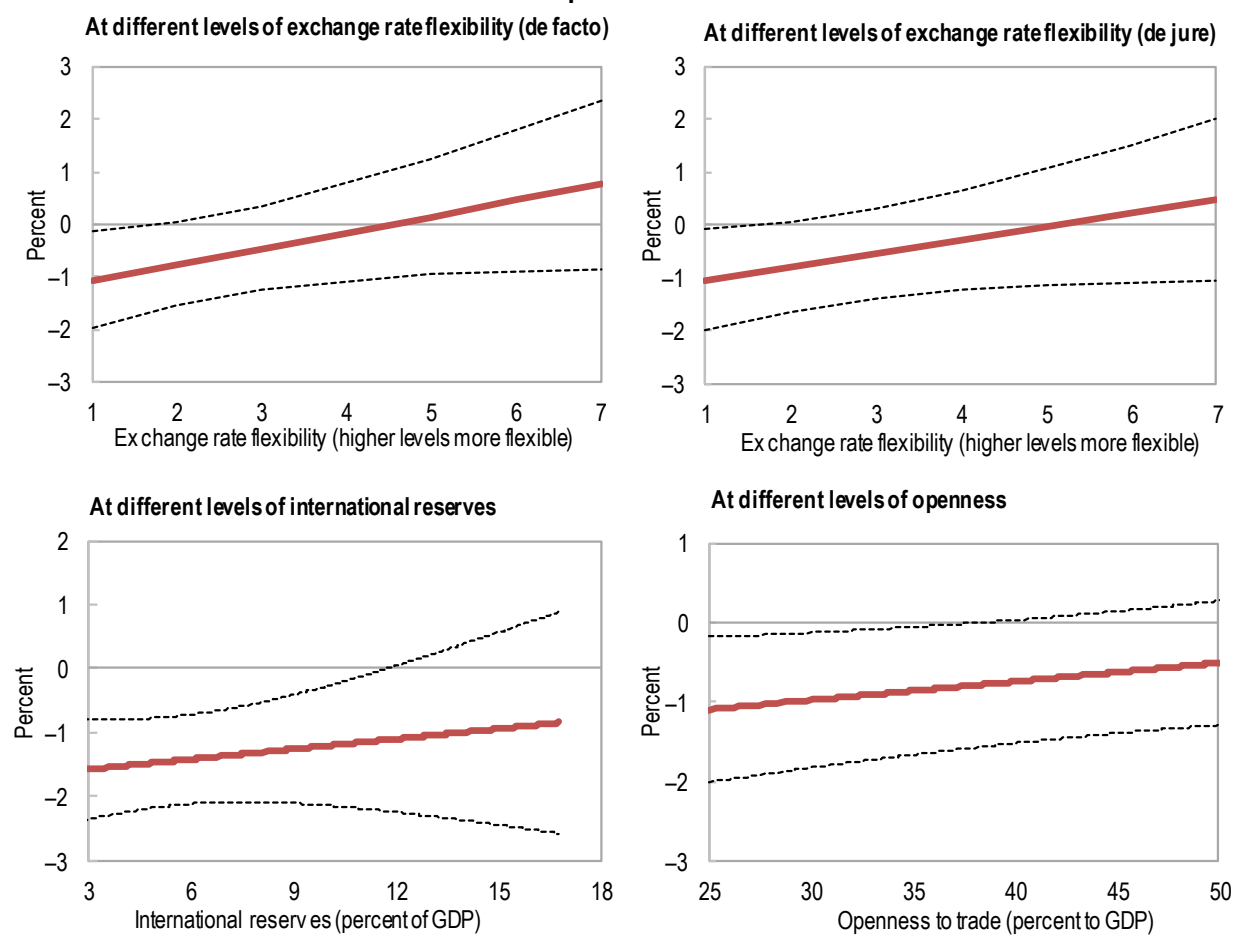

Sources: IMF, World Economic Outlook database; Penn World Table 9.0; and IMF staff calculations.

Note: The panels present the marginal effect on output for different levels of exchange rate flexibility, international reserves, and openness following a spending-based fiscal consolidation. Dashed lines indicate 90 percent confidence bands. In the case of the exchange rate flexibility measures, higher values mean more flexibility according to the IMF's Annual Report on Exchange Arrangements and Exchange Restrictions (AREAER) database. 
Figure 15. Robustness Checks: Spending-based Consolidation
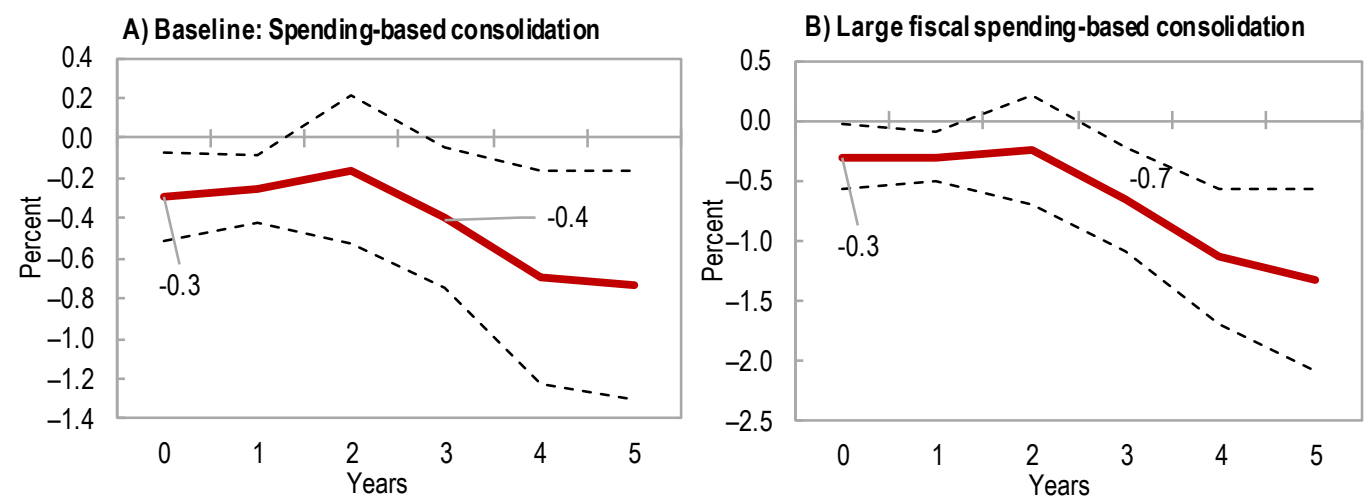

C) Sustained spending-based consolidation
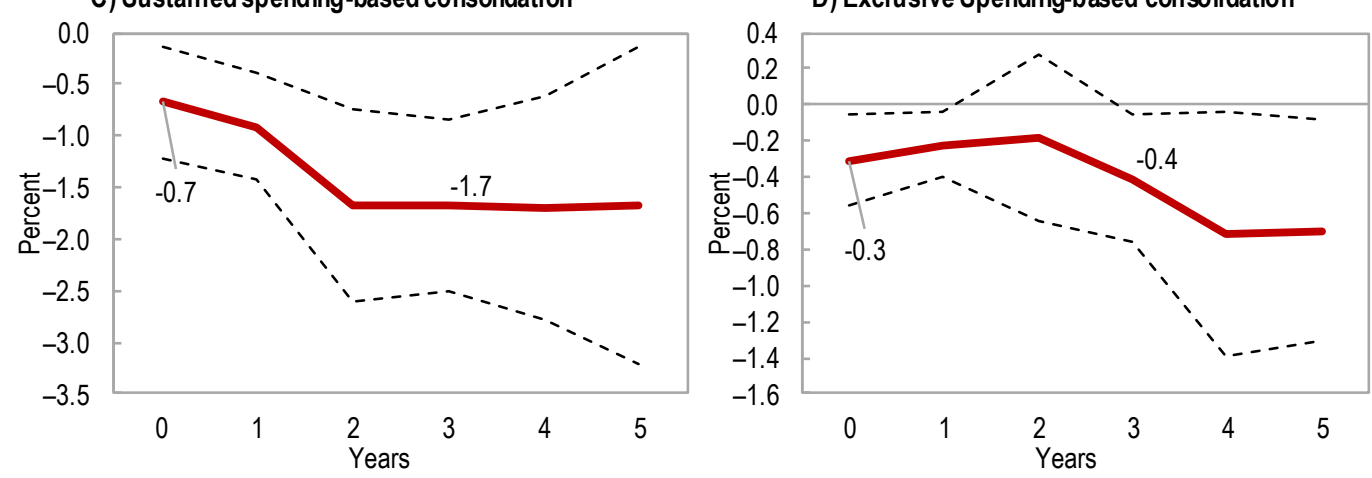

E) Exogeneity test: Spending-based consolidation
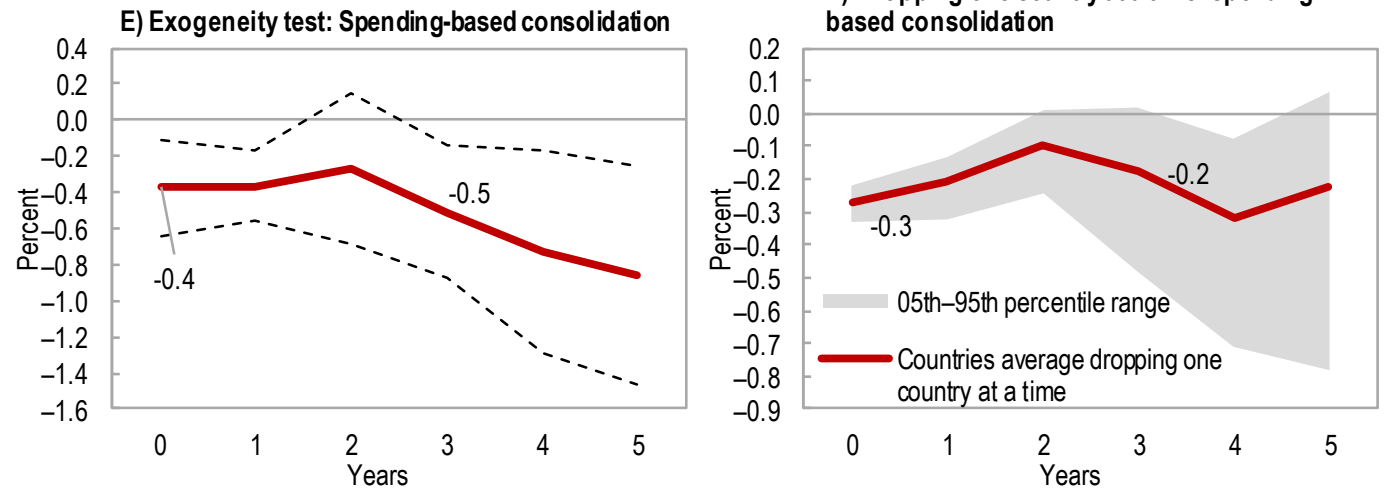

Source: IMF, World Economic Outlook database, and IMF staff calculations.

Note: Dashed lines indicate 90 percent confidence bands. $p p=$ percentage point. 
Table 1. Variables and sources

\begin{tabular}{|c|c|c|}
\hline Description & Details & Source \\
\hline Real GDP growth & Percent change & WEO \\
\hline Real GDP per capita growth & Percent change & WEO \\
\hline Public consumption & Percent of GDP & WEO \\
\hline Public investment & Percent of GDP & WEO \\
\hline Total government expenditure & Percent of GDP & WEO \\
\hline Primary government expenditure & Percent of GDP & WEO \\
\hline Capital government expenditure & Percent of GDP & WEO \\
\hline Total government revenue & Percent of GDP & WEO \\
\hline Tax revenue & Percent of GDP & WEO \\
\hline Commodity revenues & Percent of GDP & WEO \\
\hline Noncommodity revenues & Percent of GDP & WEO \\
\hline Overall fiscal balance & Percent of GDP & WEO \\
\hline Total public debt & Percent of GDP & FAD \\
\hline External debt & Percent of GDP & WEO \\
\hline General/central government & Dummy variable & WEO \\
\hline Public investment efficiency (PIEX) & 0-1 scale & FAD \\
\hline Broad money & Percent change & WEO \\
\hline Inflation & Consumer price index, percent change & WEO \\
\hline Claims on private credit & Percent change & IFS \\
\hline International reserves & Percent of GDP & WEO \\
\hline Trade openness & Exports plus imports as percent of GDP & PWT 9.0 \\
\hline Commodity terms of trade & Index, based on commodity prices and net commodity exports & April 2016 REO: SSA \\
\hline Oil exporters & Dummy ( 1 or 0$)$ & WEO \\
\hline Trading partners growth & Percent change & GEE \\
\hline De facto exchange rate regime & $\begin{array}{l}\text { DF: } \text { Hard }=1, \text { conventional }=2 \text {, basket }=3 \text {, band }=4 \text {, crawl }=5 \text {, } \\
\text { managed }=6 \text {, independent }=7\end{array}$ & October 2016 REO: SSA \\
\hline De jure exchange rate regime & $\begin{array}{l}\text { DJ: Hard }=1, \text { conventional }=2 \text {, basket }=3, \text { band }=4, \text { crawl }=5 \text {, } \\
\text { managed }=6, \text { independent }=7\end{array}$ & October 2016 REO: SSA \\
\hline Value-added agriculture & Percent of GDP & WDI \\
\hline Gini coefficient & Gini index (World Bank estimate) & WDI \\
\hline Health expenditure & Percent of GDP & WDI \\
\hline Education expenditure & Percent of GDP & WDI \\
\hline Social safety nets & Percent of population & ASPIRE \\
\hline Bureaucracy & 0-4 scale; higher numbers are better & ICRG \\
\hline Corruption & 0-6 scale; higher numbers are better & ICRG \\
\hline Law and order & 0-6 scale; higher numbers are better & ICRG \\
\hline
\end{tabular}

Note: ASPIRE = World Bank, Atlas of Social Proection Indicators of Resilience and Equity; DSA = IMF, Debt Sustainability Analysis; FAD = IMF, Fiscal Affairs Department database; GEE= IMF, Global Economic Environment database; ICRG = International Country Risk Guide database; IFS = IMF, International Financial Statistics database; PWT = Penn World Tables 9.0; REO:SSA = Regional Economic Outlook: Sub-Saharan Africa; WDI = World Bank, World Development Indicators database; WEO = IMF, World Economic Outlook database.

\section{CInternational Monetary Fund. Not for Redistribution}


Table 2. Estimated Fiscal Multipliers in the Literature

\begin{tabular}{|c|c|c|c|c|c|}
\hline Source & Group & Variable & 1 Year & 2 Years & 3 Years \\
\hline Abiad, Furceri, and Topalova 2016 & Advanced Economies & Investment & 0.8 & 1.0 & 1.5 \\
\hline Blanchard and Leigh 2013 & Europe & $\begin{array}{l}\text { Structural fiscal } \\
\text { balance }\end{array}$ & 1.1 & $\ldots$ & $\ldots$ \\
\hline \multirow{3}{*}{$\begin{array}{l}\text { Gonzalez-Garcia, Lemus, and Mrkaic } \\
2013\end{array}$} & \multirow{3}{*}{ Developing economies } & Investment & 0.4 & 0.6 & $\ldots$ \\
\hline & & Consumption & 0.4 & 0.3 & $\ldots$ \\
\hline & & Taxes & -0.1 & 0.5 & $\ldots$ \\
\hline \multirow{4}{*}{ Ilzetzki, Mendoza, and Vegh 2013} & \multirow{2}{*}{ High-income countries } & Consumption & 0.4 & 0.5 & 0.6 \\
\hline & & Investment & 0.9 & 1.2 & 1.3 \\
\hline & \multirow{2}{*}{ Developing economies } & Consumption & 0.2 & -0.1 & -0.4 \\
\hline & & Investment & 1.5 & 1.6 & 1.6 \\
\hline Kraay 2012 & Aid-dependent economies & Spending & 0.5 & $\cdots$ & $\cdots$ \\
\hline \multirow{4}{*}{ Ilzetzki 2011} & \multirow{2}{*}{ High-income countries } & Spending & 0.9 & 1.0 & 1.1 \\
\hline & & Taxes & -0.1 & -0.1 & -0.2 \\
\hline & \multirow{2}{*}{ Developing economies } & Spending & 0.4 & 0.3 & 0.2 \\
\hline & & Taxes & -0.4 & -0.6 & -0.8 \\
\hline \multirow{4}{*}{ IMF 2008} & \multirow{2}{*}{ Advanced economies } & Spending & $\ldots$ & $\ldots$ & 0.5 \\
\hline & & Revenue & $\ldots$ & $\ldots$ & -0.4 \\
\hline & \multirow{2}{*}{ Emerging economies } & Spending & $\ldots$ & $\ldots$ & -0.2 \\
\hline & & Revenue & $\ldots$ & $\ldots$ & -0.2 \\
\hline
\end{tabular}

Source: Author's calculation.

Note: Note: The figures show the effects of increases in spending and public revenue, thus expected signs are positive and negative, respectively. Boldface type denotes significance at least at the 0.10 level.

Table 3. Comparison of Fiscal Multipliers

\begin{tabular}{cccc}
\hline \multicolumn{4}{c}{ ( $p$-values for tests for equal magnitude) } \\
\hline Year & $\beta^{\mathrm{I}}=\beta^{\mathrm{C}}$ & $\beta^{\mathrm{I}}=-\beta^{\mathrm{R}}$ & $\beta^{\mathrm{C}}=-\beta^{\mathrm{R}}$ \\
0 & 0.16 & 0.11 & 0.87 \\
1 & $\mathbf{0 . 0 3}$ & $\mathbf{0 . 0 0}$ & 0.50 \\
2 & 0.43 & $\mathbf{0 . 0 6}$ & 0.22 \\
3 & 0.63 & $\mathbf{0 . 0 5}$ & 0.12 \\
4 & 0.71 & 0.73 & 0.42 \\
5 & 0.20 & $\mathbf{0 . 0 9}$ & 0.81 \\
\hline
\end{tabular}

Source: Author's calculation.

Note: $\mathrm{I}$ = investment, $\mathrm{C}=$ consumption, $\mathrm{R}=$ revenue.

Bold font denotes rejection of the hypothesis of equal magnitude of multipliers.

\section{CInternational Monetary Fund. Not for Redistribution}

